\title{
IMPACT OF FORENSIC ACCOUNTING ON FINANCIAL FRAUD DETECTION IN DEPOSIT MONEY BANKS IN NIGERIA
}

\section{Edward Idemudia Agboare}

Department of Accounting, Faculty of Management Sciences, Benue State University.

Cite this article:

Edward Idemudia Agboare (2021), Impact of Forensic Accounting on Financial Fraud Detection in Deposit Money Banks in Nigeria. African Journal of Accounting and Financial Research 4(3), 74-119. DOI:

10.52589/AJAFR-RUCOSOIQ.

\section{Manuscript History}

Received: 9 Oct 2021

Accepted: 1 Nov 2021

Published: 14 Nov 2021

Copyright $\left({ }^{\circ} 2020\right.$ The Author(s). This is an Open Access article distributed under the terms of Creative Commons AttributionNonCommercial-NoDerivatives 4.0 International (CC BY-NC-ND 4.0), which permits anyone to share, use, reproduce and redistribute in any medium, provided the original author and source are credited.
ABSTRACT: The study examines the impact of forensic accounting on financial fraud detection in Deposit Money Banks (DMBs) in Nigeria. Survey research design was employed for the study with extensive reliance on primary data obtained through the use of structured Likert scale questionnaire. The data were tested using descriptive statistics and regression analysis on Statistical Package for Social Sciences (SPSS version 20.0). The study findings showed that forensic accounting techniques of conducting investigation, analyzing financial transactions and reconstructing incomplete accounting records have significant effect on financial fraud detection in deposit money banks in Nigeria. In the light of the study findings, the following recommendations were provided; more forensic accountants should be employed by DMBs in Nigeria to assist curb modern day financial fraud brought about by advancement in technology. The Central Bank of Nigeria (CBN) should in collaboration with all financial institutions establish an electronic fraud risk information center staffed with forensic accountants. DMBs should incorporate automated control measures such as biometric authentication of transactions to serve as deterrent for fraud occurring.

KEYWORDS: Forensic Accounting, Financial Fraud Detection, Deposit Money, Banks. 


\section{INTRODUCTION}

\section{Background to the Study}

Forensic accounting, in recent years, can be said to be gaining more awareness as stakeholders are seeking more enhanced methods of curbing the menace of fraud. Since its emergence as a tool for detecting fraud, it has become a very important subject among researchers and scholars in various countries. Forensic accounting can be described as the practice of utilizing accounting, auditing and investigative skills to assist in legal matter and the application of specialized body of knowledge to the evidence of economic transaction and reporting suitable for the purpose of establishing accountability or valuation of administrative proceeding. In wide sense, it can be said to be the integration of accounting, auditing and investigative skills to obtain a particular result (Mukoro et al, 2014). Stanbury and Paley-Menzies (2010) also defined Forensic accounting as the science of gathering and presenting information in a form that will be accepted by a court of jurisprudence against perpetrators of economic crime

Fraud, on the other hand, cannot be effortlessly detected, prevented or deterred in any situation or setting, either in the home, an organization or society at large without the reviewer having adequate training and skill on fraud detection. The Association of Certified Fraud Examiners defined fraud as the use of one's occupation for personal enrichment through deliberate misuse of the employing organization's resources or assets. It is therefore any act of misappropriation, theft or embezzlement of corporate assets in a particular economic environment (Efiong, 2013).

Nwaze (2012) defined fraud as a predetermined as well as planned tricky process or device usually undertaken by a person or group of persons with the sole aim of cheating another person or organization to gain ill-gotten advantage which would not have accrued in the absence of such deceptive procedure. Fraud can be described as the use of dishonesty or trickery means with the aim of gaining undue advantage, evading a commitment, or causing loss to person, a group of persons or an organization. Fraud refers to a thoughtful act that commonly consist of the use of deception, in the form of an intentional dishonesty or a willful misrepresentation of a material fact, to acquire some form of financial value or advantage from a situation of authority or trust that ultimately results in some form of loss to the organization deceived.

With the advancement in technology around the globe, there is a massive change in the way banks as well as their customers do business, which place more reliance on the use of electronic medium, the nature of fraud and fraudulent practices has also changed and requires a timely and professional approach to avoid the inherent risk and losses associated with fraud. According to the Centre for Forensic Studies (2010) report, the increasing need for forensic and investigative accounting in the banking sector results from the nature of modern-day banking that involve large volume of complex data, which makes it difficult to monitor those transactions by applying manual audit processes. Virtually all the weaknesses and challenges identified in the banking industry in Nigeria's post-consolidation (such as inadequate system based controls, insider trading, creative accounting to boost financials by carrying unrealizable assets with huge values, etc.) and criminal investigations and prosecutions arising from them, are issues for forensic accounting.

Authors such as McMahon, Serrato, Bressler and Bressler, (2015), Zimbleman, Albrecht, Albrecht and Albrecht (2012) and Bressler, (2011) revealed that of the different fraud prevention and detection mechanisms that are being adopted to combat the menace of fraud, 
forensic accounting techniques appears to be the most effective and currently used in most developed countries of the world (Efiong, 2013). There is need to consider how forensic accounting impacts on fraud detection in deposit money banks in Nigeria. If well applied, forensic accounting could be used to reverse the leakages that cause corporate failures, this is because of the fact that forensic accounting is a technique that encapsulates accounting, auditing and investigative skills to address issues relating to financial fraud (Enofe Agbonkpolor \& Edebiri, 2015). Owojori and Asaolu (2009) opined that there is an alarming increase in the number of fraud and fraudulent activities in various sectors in Nigeria calling for the use of forensic accounting services.

In the light of the aforementioned, the study was undertaken to review the effectiveness of the components of forensic accounting in financial fraud detection in the deposit money banks in Nigeria; the study specifically considered three of such components, which included conducting investigation, analyzing financial transactions and reconstructing incomplete accounting records.

\section{Statement of the Problem}

Every organization make consented effort to distant itself from fraud and fraudulent activities, knowing the effect it can have on both the performance and corporate image. As organizations are working hard to curtail this menace, the fraudsters are also developing new methods. Recent rise in bank frauds such as look-alike frauds, card payment frauds, dud cheques, compromise of customer details, call for tightening of security mechanism (Khanna \& Arora, 2009). With this, security is a fundamental and increasingly important issue in today's banking industry (Kanniainen, 2010). In the quest to ensure the security of resources on behalf of its owners, customers and the general public, deposit money banks are constantly looking out for better ways to tackle the menace called fraud. Forensic accounting as a method for curbing fraud and fraudulent activities is gaining wider awareness and acceptance globally.

Owojori and Asaolu (2009) reveal that there is an alarming increase in the number of fraud and fraudulent activities in various sectors in Nigeria calling for the use of forensic accounting services. A number of studies such as Enofe, Agbonkpolor and Edebiri (2015), Modugu and Anyaduba (2013) and Okunbor and Obaretin (2010), had been done on the concept of forensic accounting services in Nigerian banks. Notwithstanding the volume of research work dedicated to the topic of forensic accounting, the nature of the recommendations from each of them advocates that this area of research work to more validate empirical findings. To the best of the researcher's knowledge there has not been satisfactory emphasis on the effectiveness of the components of forensic accounting in fraud detection, particularly empirical evidence; thus the study explored further the impact of forensic accounting on financial fraud detection in deposit money banks in Nigeria, by examining the effectiveness of conducting investigation, analyzing financial transactions and reconstructing incomplete accounting records on financial fraud detection in deposit money banks. The researcher is of the opinion that the effectiveness of these components in detecting fraud have not been studied considering the changes that advancement in technology has brought to banking in Nigeria, therefore justifying the need for the study. 


\section{Objectives of the Study}

The broad objective of this study was to assess the impact of forensic accounting on fraud detection in Deposit Monsey Banks (DMBs) in Nigeria. The specific objectives of the study are:

a. To examine the effectiveness of conducting investigation on financial fraud detection in DMBs;

b. To ascertain the effectiveness of analyzing financial transactions on financial fraud detection in DMBs;

c. To establish that reconstructing incomplete accounting records can be effective in detecting financial fraud in DMBs.

\section{Research Questions}

In relation to the above stated objectives, the following research questions were formulated which will form the basis of the study.

i. To what extent is conducting investigation effective in financial fraud detection DMBs in Nigeria?

ii. To what extent is analyzing financial transactions effective in financial fraud detection in DMBs in Nigeria?

iii. To what extent is reconstructing incomplete accounting records effective in detecting financial fraud in DMBs in Nigeria?

\section{Statement of Research Hypotheses}

For the purpose of this study, the following null hypothesis are proposed to guide the study

i. Conducting investigation has no significant effect with regards to financial fraud detection in DMBs in Nigeria.

ii. Analyzing financial transactions has no significant effective on financial fraud detection in DMBs in Nigeria.

iii. Reconstructing incomplete accounting records has no significant effect in detecting financial fraud in DMBs in Nigeria.

\section{Significance of the Study}

The study is on the impact of forensic accounting on fraud detection in Deposit Money Banks in Nigeria. The study is expected to be beneficial to the following:

For the management of the banks in Nigeria, this study will bring about increased awareness on the need to further establish a more aggressive system of accounting and other related control measures that can be applied electronically over the operation of their organization as a positive step towards detecting and preventing financial fraud, as the fraudsters are not sleeping themselves. 
The existing and potential investors will benefit from the study, as the study will enlighten investors on the importance of forensic accounting and its effectiveness in combating fraud and fraudulent activities in banking activities, thus assist them make informed decision on investment in the sector. Potential investors will pursue investment in companies that have reduced fraudulent activities owing to proper policies like integration of forensic accounting.

The study will be of benefit to the government through the Apex bank in formulating of guidelines towards increasing effectiveness of forensic accounting to reduce the extent of frauds occurring in deposit money banks. It will also help the legislators to lobby for forensic experts to be involved in the formation, amendment of various accounting practices and therefore enable them to be more applicable and relevant in the banking sector.

The confidence of deposit money banks' customers and the general public will be renewed as they can ascertain with some degree of reliability that the banking sector in Nigeria is taking adequate measures to safeguard itself, it customers and the society at large. Stakeholders in the sector will benefit from the study as it provides insight to the subject matter and its importance to both the private and public sector. It will also boost their confidence as well as that of the international community in the Nigerian banking sector

This study will add to existing knowledge on the subject of forensic accounting and fraud and provide a source of reference to further empirical studies into the little known ways of fraudulent practices in banks. This study will be found useful to students, lecturers and other scholars. It will also serve as a basis for further research in similar area. It will also forms the basis for future researchers and academicians who may be conducting research on roles and effectiveness of forensic accounting and its application in the banking industry.

\section{Scope of the Study}

The scope of the study comprises of banks in the Nigerian banking sector as categorized by the Central Bank of Nigeria, this include deposit money banks, merchant banks and financial holding companies. This study examined the post-consolidation period in the Nigerian banking sector, which is a period of twelve (12) years, from 2006 to 2017.

\section{REVIEW OF RELATED LITERATURE}

\section{Conceptual Framework}

The following concepts are hereby clarified: Forensic Accounting and Fraud.

\section{Forensic Accounting}

Forensic accounting integrate an understanding of accounting principles with investigative techniques to determine whether the actions behind financial records and statements are suspicious. Forensic accounting is the practice of utilizing accounting auditing and investigative skills to assist in legal matter and the application of specialized body of knowledge to the evidence of economic transaction and reporting suitable for the purpose of establishing accountability or valuation of administrative proceeding. In wide sense, it can be said as the integration of accounting, auditing and investigative skills to obtain a particular result (Mukoro, Faboyede \& Eziamaka, 2014). Stanbury and Paley-Menzies (2010) also 
defined Forensic accounting as the science of gathering and presenting information in a form that will be accepted by a court of jurisprudence against perpetrators of economic crime. The AICPA defines forensic accounting as services that involve the application of specialized knowledge and investigative skills possessed by Certified Public Accountants. Forensic accounting services utilize the practitioner's specialized accounting, auditing, economic, tax, and other skills (AICPA, 2010). Singleton and Singleton (2006) opined that forensic accounting comprehensively entails fraud investigation, prevention of fraud and analyzing antifraud controls in addition to gathering non-financial information. Hopwood, Leiner and Young (2008) defined forensic accounting as the application of investigative and analytical skills for the purpose of resolving financial issues in a manner that meets standards required by courts of law. They asserted, however, that while forensic accounting may not make explicit reference to fraud, fraud investigations are integral part of forensic accounting.

Dhar and Sarkar (2010) averred that forensic accounting is the application of accounting concepts and techniques to legal problems. It demands reporting where fraud, bribery or embezzlement is established and the report is considered as evidence in the court of law or in administrative proceedings. Arokiasamy and Cristal (2009) opined that forensic accounting is the application of financial skills and investigative mentality to unsettled issues, conducted within the context of the rules of evidence. Zadeh and Ramazani (2012) are of the view that Forensic accountants provide services in accounting, auditing investigation, damages claims, analysis valuation and general consultation and also have critical roles in divorce, insurance claims, personal damage claims, fraud claims, construction, auditing of publication right and in detecting terrorism by using financial precedence.

Howard and Sheetz (2006) defined forensic accounting as the process of interpreting, summarizing and presenting complex financial issues clearly, succinctly and factually in a court of law as an expert. Okunbor and Obaretin (2010) added that it is concern with the use of accounting discipline to help determine issues of facts in business litigation. Forensic accounting, if well applied, could be used to reverse the leakages that cause corporate failures; this is because of the fact that forensic accounting is a technique that encapsulates accounting, auditing and investigative skills to address issues relating to financial fraud. It went on to state that the increasing need for forensic and investigative accounting in the banking sector for the complexities of modern-day banking with large volume of complex data cannot be overemphasized (Enofe Agbonkpolor \& Edebiri, 2015).

\section{Need for Forensic Accounting}

Aduwo, (2016) opined that the need for forensic accountant aroused because of the failure of audit system in organizations to reveal certain errors in the managerial system. Experts in the field pointed out that economic pressure with many companies facing bankruptcy jobs and employees support managers, thereby giving room for employees and managers to commit financial and economic crimes. Forensic accountants are therefore called upon to meticulously search through documents, to discover new information and help in putting together the pieces of company's financial puzzle to solve the financial problems. Aduwo put forth the following as important reasons for the growth of forensic accounting: 
- Internal audit and audit committee could not throw light on the different fact and other hidden aspects of corporate fraud.

- The method of appointing the statutory auditors involves lobbying and the certificates of the auditors are hardly scrutinized especially when the reports are qualified.

- The internal auditors can surely detect financial frauds but they are in difficult position to initiate proper action on fraud matters.

\section{Responsibilities of Forensic Accountants in Detecting Fraud}

A forensic accountant should perform the following responsibilities as listed below:

\section{a. Conducting Investigation}

Owojori and Asaolu (2009), state that the failure of the statutory audit and the sophisticated financial fraud in recent times had led to the need for forensic audit. Thus, the forensic accountant could be said to have special tools for conducting investigation as to detect and prevent fraudulent activities thereby combating financial fraud. Zimbleman (1997), states that a forensic accountant being a fraud investigator is very much likened to a physician who requires significant amount of diagnostic and explanatory work to discover what really is happening. In view of the above, it can be said that a forensic accountant goes beyond the normal audit as to unveil fraudulent activities by using forensic software tools in conducting and investigating transactions and events.

Cabole (2009), states that a forensic accountant does the following: Fraud detection, documentation and presentation in criminal trails and claims; Calculate economic damages, trace income and assets, often in an attempt to find hidden assets or income; Reconstruction of financial statements that may have been destroyed or manipulated; and Expert witness.

\section{b. Analyzing Financial Transactions}

Cole (2009), states that a forensic accountant is required to have special skills in inspecting documents for authenticity, alteration, forgery or counterfeiting. Hence, by possessing such skills, the forensic accountant in carrying out his duties can easily detect errors, fraudulent activities and omissions thereby preventing and reducing fraudulent activities. Zimbleman, Albrecht, Albrecht and Albrecht (2012), states that a forensic accountant is responsible for analyzing and identifying the kinds of fraud that could occur and their symptoms.

\section{c. Reconstruction of Incomplete Accounting Records}

A forensic accountant in carrying out his function reconstructs incomplete accounting records to settle for example insurance claims, over inventory valuation, proving money laundering activities by reconstructing cash transactions (Owojori \& Asaolu, 2009).

The above responsibilities listed by Cabole (2009) shows that a forensic accountant must be an expert in financial matters and must have vast knowledge in wider areas which could enable him detect fraudulent activities as soon as one is spot. 


\section{Fraud}

Fraud like most social and management concept does not have a definite definition, it is mostly defined base on the circumstance in which it occurred; it has been describe by many researchers that defining fraud is as difficult as identifying it.

Fraud is any deliberate deceitful conduct or omission designed to gain an advantage to which a person or entity is not entitled. It is the intentional use of false representations or deception to avoid an obligation, gain unjust advantage or in the context of public administration, commonly referred to as 'rorting the system' - that is to take unfair advantage of something (Watterston 2014). Fraud is an act of dishonesty in which illegal means are used to acquire or benefit from resources belonging to others (Damagum, 2005). Archibong (1992) described the concept as a predetermined and well planned tricky process or device usually undertaken by a person or group of persons, with the sole aim of checking another person or organization, to gain ill-gotten advantages, be it monetary or otherwise, which would not have accrued in the absence of such deceitful procedure.

Kanu and Okorafor, (2013) described fraud as anything calculated to deceive, whether by a single act or combination or by suppression of truth or suggestion of what is false whether it be by direct falsehood or innuendo, by speech or silence, word of mouth, look or gesture.

Anti-fraud professionals agree that fraud (and misconduct) encompasses activities involving dishonesty and deception that can drain value from a business, either directly or indirectly, whether or not the perpetrator(s) benefit. Fraud involves the intent to defraud; that is, the perpetrator relies on his or her deception to accomplish - or hide - the fraudulent activity. Fraud is not accomplished via honest mistake or error (Tilton, 2006)

From the above definitions and descriptions, irrespective of the vocabulary used, fraud can be viewed as a means of obtaining the resources of others or organization in a wrong manner, because defrauding people or entities of monies or valuables is the common purpose of any fraudulent act. Fraud is perhaps the most fatal of all the risks confronting banks. The enormity of bank fraud in Nigeria can be inferred from its value, volume and actual loss.

\section{Forms of Fraud}

According to Adebisi (2009), there are three forms of fraud. They are the internal, external and a combination of internal and external frauds which is often referred to as "collusion".

The Association of Certified Fraud Examiners (ACFE) categorizes fraud threats to businesses in the following ways: Asset misappropriation, fraudulent financial statements and records, and Corrupt or prohibited practices.

\section{a. Asset Misappropriation}

Simply put, asset misappropriation can be thought of as a theft of something of value that belongs to your business. Asset misappropriation fraud happens when people who are entrusted to manage the assets of organization teal from it. Asset misappropriation involves third parties or employees in an organization who abuse their position to steal from it through fraudulent activities. When it comes to asset misappropriation, "cash is king." In other words, cash is the most frequently targeted asset. Cash targets include currency and coins, checks, electronic 
funds, financial instruments, rebates, credits, discounts, and virtually any other device or means of financial exchange or enrichment. Cash is targeted for obvious reasons - it has a clearly known value, is easily transferable and transportable, is difficult to trace, and may even be diverted before any record exists on company books. Cash may be targeted by external or internal perpetrators or even by both via collusion.

\section{b. Fraudulent Financial Statements, Books, and Records}

The financial statements (internal and external), books, and records of a business may also be targets for fraud. Specifically, they may be: Manipulated to hide fraud, for instance to prevent discovery of an asset misappropriation, and/or; Falsified to accomplish a fraud to cause unjustified financial rewards, such as executive bonuses based on falsified financial performance data).

\section{c. Corrupt or Prohibited Practices}

Corrupt and prohibited business practices include the following closely related concerns: Side agreements, involving undisclosed rebates or kickbacks, and Bid-rigging, bribery, and extortion. Corrupt and prohibited practices often involve hidden arrangements with customers and suppliers of goods and services to a company. In many cases, these arrangements directly and dishonestly benefit the individual employee(s) involved. (Tilton, 2006)

\section{Bank Fraud}

Bank fraud is the use of fraudulent means to obtain money, assets, or other property owned or held by a financial institution. While the specific elements of a particular banking fraud law vary between jurisdictions, the term bank fraud applies to actions that employ a scheme or artifice, as oppose bank robbery or theft. For this reason, bank fraud is sometimes considered a white collar crime. Oboh (2005) states that banks being the main channel for remitting and processing funds are left highly vulnerable to the nefarious activities of the perpetrators of economic and financial crime. The damaging effect of which is immeasurable both on the side of the banks and as well as the general economic system. Abiola (2009) buttress on that fraud and management have been the participating factors in the distress of banks, and as much as various measures have been taken to minimize the incidence of fraud, it still rises by the day because fraudsters always device tactical ways of committing fraud. Bank fraud as described by Abiola (2009), can be classified into three, that is: by flow, by victims and by act. Flow frauds describe the frequency and the value involved in the fraud, which are basically two type; the first are those that are not frequent but the value is high in a short period of time this is referred to as Smash and Grab, and the second are those that are frequent, small in value and repetitive over a period of time this is referred to as Frip Fraud. Victim fraud classification is based on those affected by loss from fraud, which could be either those against the company (bank) or those against outsiders. Lastly, Act frauds is the action that takes place in cases of fraud, that is the people involved and the methods or form by which these people perpetrate fraud. 


\section{Electronic Banking Fraud}

Banking system is the lifeblood and backbone of the economy. Information Technology has become the backbone of the banking system. It provides a tremendous support to the ever increasing challenges and banking requirements. Presently, banks cannot think of introducing financial product without the presence of Information Technology (Reddy, 2009). Electronic crimes can be of a variety of types such as Telecommunications Piracy, Electronic Money Laundering and Tax Evasion, Sales and Investment Fraud, Electronic Funds Transfer Fraud etc.

From the security assessment of Nigerian banks, e-fraudsters had in recent years invaded Nigeria's banking platforms at will, deploying over 185 fake mobile applications on the websites of no fewer than 15 deposit money banks in the country and in the process, extracted customers' personal and financial information with intent to defraud billions of naira from their accounts (Nwosu, 2015)

Credit card fraud has become ordinary on internet which not only affects card holders but also online merchants. Credit card fraud can be completed by taking over the account, skimming or if the card is stolen. The term "Internet fraud" refers usually to any type of fraud scheme that uses one or more components of the Internet - such as chat rooms, e-mail, message boards, or Web sites - to existing fraudulent solicitations to prospective victims, to conduct fraudulent transactions, or to broadcast the proceeds of fraud to financial institutions or to other connected with the scheme (Ahuja, 2010).

However, of late, as stolen identities seem to have served as the 'hacking channel' for most of the cyber-criminals, analysts generally believe that improper management of the Administrative Passwords, which are often aptly referred as 'Keys to the Kingdom', is at the root of many security threats. Another harsh fact is that many a sabotage had been caused by the insiders of the enterprises. Keltie (2009) opined that most frauds are committed by or involve an insider, typically an employee in a position of trust. When an organization suspects that it is the victim of an employee fraud, often the first thing it does is launch an internal investigation.

There are also concerns about whether information is being transferred securely and if there is a risk of sensitive information being exposed. As mobile payments become equipped with security features such as tokenization and biometric authentication which do not impact their usability, they will be more widely accepted as a payment solution (McDonnell, 2015). 


\section{Theoretical Framework}

The following theories relevant to this study are hereby reviewed.

\section{The Fraud Triangle Theory}

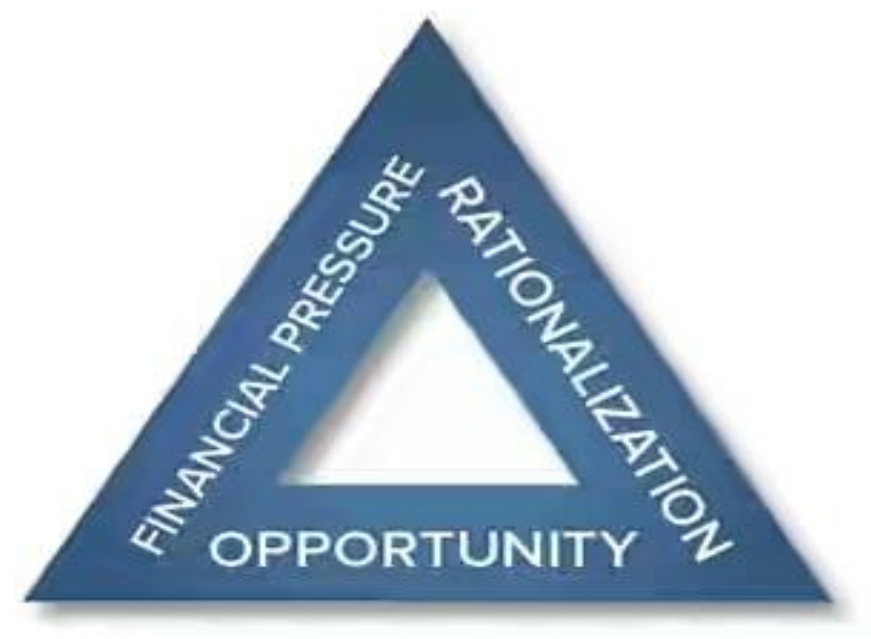

Figure 2.1: Fraud triangle

Source: Researchgate.net

The Fraud Triangle Theory was propounded by Donald Cressey in 1950. Donald Cressey, a criminologist, started the study of fraud by arguing that there must be a reason behind everything people do. The fundamental observation of Donald Cressey (1919-1987), in the Fraud Triangle Theory was that fraud is likely to occur given a combination of three factors. This theory is made of a triangle of different fraud aspects that include perceived opportunities, perceived pressures and rationalizations (Chiezey \& Onu, 2013). Ngalyuka (2013) maintains that the term perceived is vital in the context that the pressures, rationalizations, and opportunities may not necessarily be real. Chiezey and Onu, (2013) put forth that financial and non-financial pressures present the first temptation to commit frauds. Ngalyuka (2013) stated that $95 \%$ of the committed frauds are due to financial pressures such as debts, vices such as drug abuse and work related pressures such to show good sales performance amongst others. The second factor is perceived opportunity. According to Wanyama, (2012), the perceived opportunity is the ability of the potential fraudster believing that that they can get away with the fraud or the consequences of being caught are manageable. Chiezey and Onu (2013) stated that the opportunity to commit fraud in the bank is characterized by employee access to assets and information that presents them with dual advantage of committing and concealing fraud. Kanu and Okorafor, (2013) buttressed that these opportunities are presented through weak control measures, lack of control measures enforcement, lack of sufficient punishment measures to act as a deterrence and inadequate infrastructure. The last factor contributing towards frauds is the concept of perceived rationalization. This involves rationalization or justification of the fraud aspect as acceptable (Njenga \& Osiemo, 2013). While Ngalyuka (2013) opined that rationalization refers to the justification that the unethical behavior is something other than criminal activity. 
Fraud triangle theory is relevant to the study impact of forensic accounting on fraud detection in deposit money banks in Nigeria, as the theory gives forensic accountants insight into the subject matter of fraud and the facts that can give rise to it in almost all circumstances.

\section{The Fraud Diamond Theory}

\section{The Fraud Diamond}

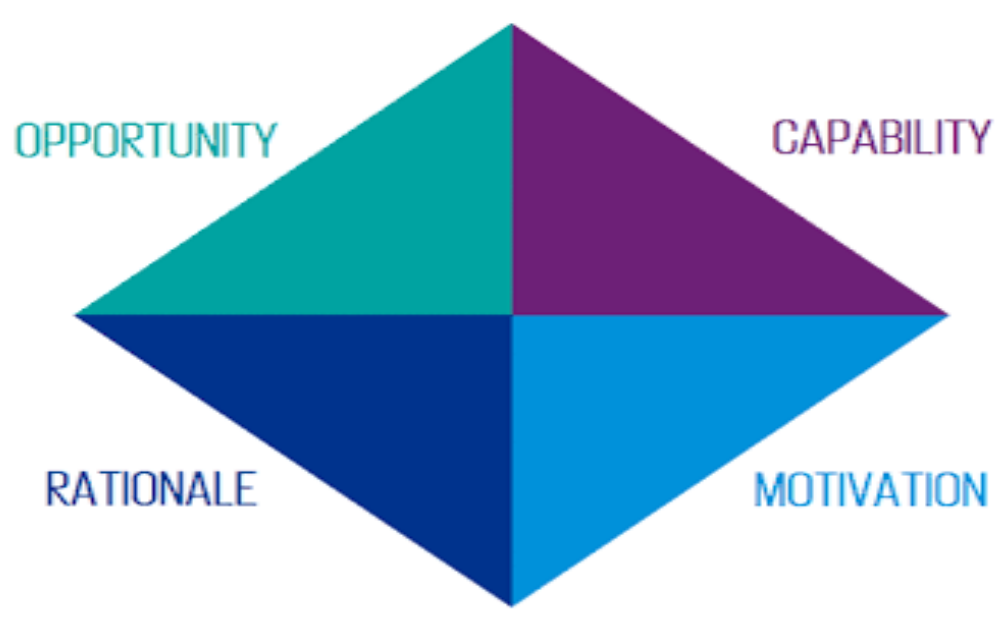

Figure 2.2: Fraud diamond

Source: Karunia dhi.blogspot.com

The Fraud Diamond Theory was first presented by Wolfe and Hermanson in the CPA Journal (December 2004). It is generally viewed as an expanded version of the Fraud Triangle Theory. In this theory, an element termed capability has been added to the three initial fraud elements of the Fraud Triangle Theory. Wolfe and Hermanson (2004) argued that although perceived pressure or incentive might coexist with an opportunity to commit fraud and a rationalization for doing so, it is unlikely for fraud to take place unless the fourth element (i.e., capability) is also present. In other words, the potential perpetrator must have the skills and ability to commit fraud.

According to Wolfe and Hermanson (2004:38) "Opportunity opens the doorway to fraud, and incentive (that is, pressure) and rationalization can draw a person toward it. However, the person must have the capability to recognize the open doorway as an opportunity and to take advantage of it by walking through, not just once, but repeatedly". With the additional element presented in the Fraud Diamond Theory affecting individuals' decision to commit fraud, the organization and auditors need to understand employees' individual traits and abilities in order to assess the risk of fraudulent behaviors in the public sector.

The elements of Fraud Diamond Theory are interrelated to the extent that an employee cannot commit fraud until all of the elements are present. The theory proposes that pressure can cause someone to seek opportunity, and pressure and opportunity can encourage rationalization. At 
the same time, none of these two factors, alone or together, necessarily cause an individual to engage in activities that could lead to fraud until the fraudster has the capability to do so (Hooper \& Pornelli, 2010). The additional element, i.e., capability is what differentiates the Fraud Diamond Theory of Wolfe and Hermanson (2004) from the Fraud Triangle Theory of Cressey (1950).

Fraud diamond theory is relevant to this study, as the theory broaden the horizon on the subject matter of fraud, stating that there must be the capability to carry out fraud for it to occur. This theory further expand the scope and perspective of forensic accountants in the bid to detect fraud.

Fraud Diamond theory gave a step further from where the fraud triangle theory stopped by adding that for fraud to occur there must also be the capability to perpetuate it. The theory is relevant to this study as it further expand the scope of what to check out for in detecting fraud. The theory also broaden the perspectives of the forensic accountant in carrying out it functions as it relate to fraud.

\section{Fraud Management Lifecycle Theory}

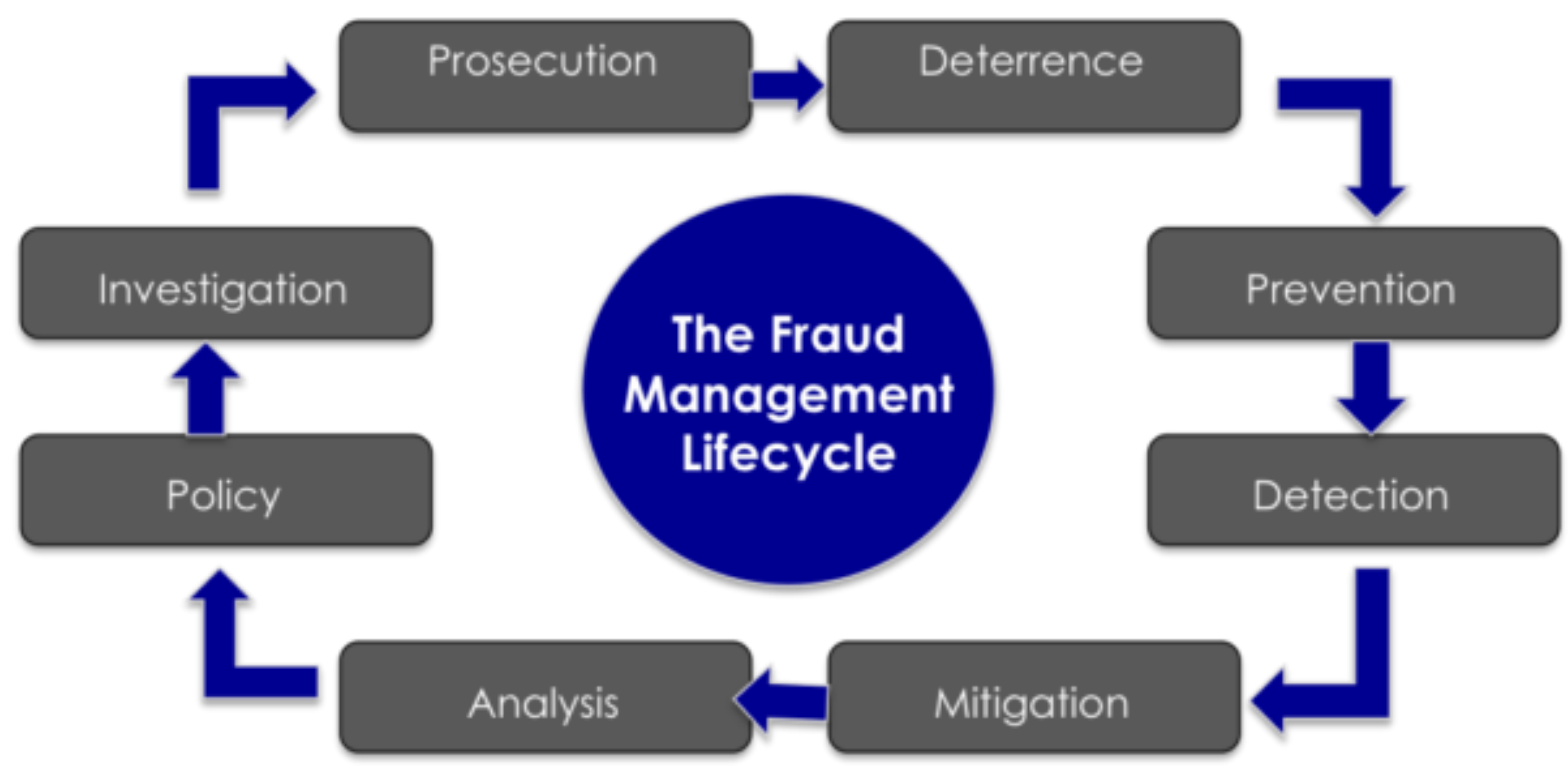

Figure 2.3: Fraud management lifecycle

Source: Arctic-intelligence.com

The Fraud Management Lifecycle Theory was first presented by Wilhelm in the Journal of economic crime management (Spring 2004, Volume 2, Issue 2). Our review of this theory is solely on the work of Wesley Kenneth Wilhelm. Fraud can only be adequately managed if all stakeholders identify and carry out their roles effectively.

Fraud management is the process of monitoring, identifying, reporting and prevention of fraud in an organization. Fraud management lifecycle highlight the inter-play of policy, process and 
people in the end-to-end handling of fraud. According to Wilhelm (2004) The Fraud Management Lifecycle is a network lifecycle where each node in the network, each stage in the lifecycle, is an aggregated entity that is made up of interrelated, interdependent, and independent actions, functions, and operations. These activities can, but do not necessarily, occur in a sequential or linear flow. Effective fraud management requires a balance in the competing and complementary actions within the Fraud Management Lifecycle. Effective management of the Fraud Management Lifecycle starts with a common understanding or definition of the stages in the lifecycle.

In his work, Wilhelm (2004) stated that the Fraud Management Lifecycle is made up of eight stages. The Fraud Management Lifecycle is dynamic, evolving, and adaptive. The eight stages are: Deterrence, Prevention, Detection, Mitigation, Analysis, Policy, Investigation, and Prosecution. Wilhelm (2004) went on to expand the stages as follows: Deterrence, the first stage, is characterized by actions and activities intended to stop or prevent fraud before it is attempted; that is, to turn aside or discourage even the attempt at fraud through. The second stage of the Fraud Management Lifecycle, prevention, involves actions and activities to prevent fraud from occurring. In detection, the third stage, actions and activities, such as statistical monitoring programs are used to identify and locate fraud prior to, during, and subsequent to the completion of the fraudulent activity. The intent of detection is to uncover or reveal the presence of fraud or a fraud attempt. The goal of mitigation, stage four, is to stop losses from occurring or continuing to occur and/or to hinder a fraudster from continuing or completing the fraudulent activity, by blocking an account, for example. In the next stage, analysis, losses that occurred despite deterrence, detection, and prevention activities are identified and studied to determine the factors of the loss situation, using methods such as root cause analysis. The sixth stage of the Fraud Management Lifecycle, policy, is characterized by activities to create, evaluate, communicate, and assist in the deployment of policies to reduce the incidence of fraud. Balancing prudent fraud reduction policies with resource constraints and effective management of legitimate customer activity is also part of this stage. Investigation, the seventh stage, involves obtaining enough evidence and information to stop fraudulent activity, recover assets or obtain restitution, and to provide evidence and support for the successful prosecution and conviction of the fraudster(s). The final stage, prosecution, is the culmination of all the successes and failures in the Fraud Management Lifecycle. There are failures because the fraud was successful and successes because the fraud was detected, a suspect was identified, apprehended, and charges filed.

The fraud management lifecycle theory was adopted for this study, this is because the theory gives a holistic approach to the subject of fraud and fraud management; also worthy of note for adopting the theory is the fact that the theory is evolving and can be adapted by any organization.

\section{Empirical Reviews}

Many researchers have attempted to examine the subject matter of forensic accounting and its impact in combating financial fraud. Several of these empirical studies were reviewed below.

Aduwo (2016) examined the role of forensic accounting in combating the menace of corporate failure. The study conceptually reviewed the impact of forensic accounting towards utilizing professional judgments, accounting skills, auditing and law procedures to fight the dreaded disease of corporate liquidation. The work merely reviewed the concepts of forensic 
accounting, auditing and corporate failure. The study concluded that forensic auditing can go a long way to influence financial scandals in corporate organizations. It recommended empirical validation of the work and with specific reference to organizations in another country.

The study was merely a conceptual review and only the concept of forensic accounting was reviewed, leaving out the aspect of corporate failure; there was also no variable tested.

Eliezer and Emmanuel (2015) examined the relevance of forensic accounting in the detection and prevention of fraud in Nigeria. The study was a theoretical research which considered the role of forensic accountants in combating fraudulent activities, differences between a forensic accountant and traditional accountant, and the impact of forensic accountants to detect and prevent fraud. From the study, it was found among others that forensic accounting services will assist audit committee members in carrying out their oversight functions by providing assurance on internal audit report. The research recommended that government should ameliorate the cost of hiring the services of forensic accountants and treat culprits equally without favoritism.

The study had not specified problem it set out to provide answers to; there were no research questions nor hypotheses stated and no variables were tested. Though the study was stated to be a theoretical review, no specific theory was reviewed in the work.

Enofe, Agbonkpolor and Edebiri (2015) examined the role of forensic accounting in curbing financial crimes in Nigerian banks. The survey research design was employed for the study with an extensive reliance on primary data retrieved through the use of well-structured Likert scale questionnaire. The chi-square non-parametric statistical technique was utilized for the data analysis procedure. The study findings show that; there is a need for forensic accountants in the Nigerian banking system, forensic accounting is an effective tool for addressing financial crimes in the banking system and there are significant differences between the roles of forensic accounting and that of conventional accounting in curbing financial crimes. The study recommended that; there is the need for banks in Nigeria to engage the services of forensic accountants, and secondly, banks also need to focus on training and up-dating the skills of the internal control and audit staffs.

The problem of the study was not clearly stated. There were no theories reviewed and only one concept (Forensic accounting) was reviewed. Hypotheses were only stated at the section for discussion of findings, which does not give the work a good structure.

Enofe, Idemudia and Emmanuel (2015) examined forensic accounting as a panacea to fraud reduction in Nigeria firms. Primary data were collected through the use of questionnaires. Data retrieved were analyzed with the help of tables, pie-chart, regression and chi-square. The findings of the study are that forensic accounting enhances financial fraud reduction in Nigeria firms through fraud prosecution and prescription of punishment for fraudsters; forensic accounting has significant effect in improving internal control systems of firms in Nigeria leading to fraud reduction; forensic accounting has significant impact on the financial reporting credibility of firms in Nigeria; forensic accounting has significant impact on firms transparency in Nigeria. The study recommended that forensic accountants should always be invited in setting up the organizational internal control system to ensure efficiency and effectiveness. 
The work was well structured and all variables stated were tested, however, the findings of the study were not discussed; it only gave a summary of the findings and there was no specific aspect of forensic accounting related in the study.

Enofe, Utomwen and Danjuma (2015) examined the role of forensic accounting in mitigating financial crime. The study adopted a survey research design and the population of the study comprised staff of selected banks from which data were collected through the use of questionnaires to test the formulated hypotheses. Regression analysis was used for data analysis. The study findings revealed that there is a need for forensic accountants in the Nigerian banking sector, forensic accounting is an effective tool for addressing financial crime in the banking sector and that conventional accounting techniques are not effective in curbing financial crimes. The study then recommended that there is need for corporations in Nigeria to engage the services of forensic accountants, they need to also focus on training and up-dating the skills of the internal control and audit staff.

Oladejo and Oluwaseun (2015) investigated the impact of forensic Accounting on reducing fraud in the Nigerian banking sector and was carried out in Lagos state on 125 senior and management staff in one of the quoted banks (Eco-Bank) in Nigeria. Data were collected through questionnaire and analyzed using descriptive statistic tool. Hypotheses were tested through chi-square statistics. The result of the findings shows that Forensic Accounting is significantly useful in fraud control and reduction in the Nigeria Banking Industry and positively influence banks performance. The study recommended that banks management should ensure the role and functions of forensic accountants and auditors clearly defined, most especially in the area of reducing fraud in the banking sector.

No recent literature was reviewed, the earliest work reviewed was a work done in 2006. For a work done in 2015, recent work on the subject should have been reviewed. The study also generally reviewed the concept of forensic accounting, with no particular mention of any aspect of forensic accounting being referred to.

Onodi, Okafor and Onyali (2015) examined the effect of forensic investigation methods in corporate fraud deterrence in Nigerian banks. Statistical tools used to analyze the data include percentages, mean score, frequency tables, regression analysis and Z-test. Three hypotheses were formulated and tested. The result revealed that there is a significant relationship between the forensic investigative methods and corporate fraud deterrence. The study recommended improvement on accounting curriculum, since there is a failure of accounting and control methods that lies in the methodology taught in Nigeria Universities to discover financial fraud cases.

The study has a clearly stated problem and objectives, it reviewed recent relevant works in the area of the study. Both primary and secondary data were used, generally the study was quite impressive; also owing to the fact that the study consider the component of investigation.

Augustine and Uagbale-Ekatah (2014) examined the relevance of forensic accounting as a tool for combating fraud and corruption. Their views were obtained through structured interviews and evaluated against known research findings on the practice of forensic accounting in Nigeria. The key findings of this study are that: forensic accounting practice is largely considered to be at its infancy stage and although it is relevant, yet it lacking statutory support. 
The study recommends among others the need to accord forensic accounting statutory role and distinct professional recognition by the government and professional bodies in Nigeria.

The study was basically descriptive in nature and portrayed the views of various stakeholders on the subject of forensic accounting, there was no clearly stated problem it sought to resolve. There was no specific mention of any aspect of forensic accounting being addressed, the study gave a general knowledge of the concept.

Mukoro, Faboyede and Eziamaka (2014) examined the effectiveness of forensic accountants in strengthening internal control of business organizations in Nigeria. The study employed survey design and purposive sampling was used to select five companies. Data were collected using questionnaires and all the hypotheses were tested using Regression Analysis. The results of the empirical findings show that internal control and its components play a significant role in controlling fraud in business organizations. It is recommended that internal control should be undertaken with effective continuous monitoring of the controls and companies should be stricter with compliance to control procedures.

The research work was well structured, however, there were not recent literature reviewed for a study done in 2014, the earliest work reviewed was a decade before the study (2004). The subject of forensic accounting was reviewed largely, there was no specific mention of any aspect of forensic accounting being addressed.

Odelabu (2014) examined the effects of forensic accounting on the performance of commercial bank in Nigeria. The sampling frame of twenty-one commercial banks was taken. A sample of sixty-one respondents was used which was spread proportionately across 6 stratum. The study used primary data that was collected through self-administered questionnaires and analyzed using regression analysis. The findings indicated that forensic investigation and forensic litigation was statistically significant in explaining changes in financial performance of commercial banks. The study recommended that majority of commercial banks in a developing economy ought to adapt forensic accounting to mitigate financial irregularities.

The study had no stated problem; while it had only one objective stated, the work had two hypotheses. Forensic accounting was reviewed broadly, there was no specific mention of any aspect of forensic accounting being addressed

Peter, Masoyi, Ernest and Gabriel (2014) examined the application of forensic auditing in fraud control in Nigerian banks. The study analyzed the trend in fraud cases from 2001 to 2012. The descriptive analysis revealed that there are up and down movements in fraud cases. The study suggested employment of forensic auditing in Nigerian banks by amending the existing statutes, in such a way that forensic auditors are included in the audit team. Through this, auditors will have more tools to effectively deal with challenges in detecting fraud.

The study had no clear-cut problem, objectives or variable stated. It merely reviewed the concept of forensic auditing and descriptively analyze fraud figures for a decade and collated by Nigeria Deposit Insurance Corporation.

Dada, Owolabi \& Okwu (2013) examined the relevance of forensic accounting in the effective reduction in fraudulent practices in Nigeria. The study was carried out on the application of forensic accounting in the investigation and detection of cases of fraud in Nigeria, using all the staff of the selected anti-corruption agent (EFCC) and three of the major professional 
accounting firms in Nigeria for the period 1999 to 2010. The study employed multiple regression technique to analyze the empirical data collected through questionnaire and oral interview and the hypothesis formulated was also tested. The results of the hypotheses tested revealed that fraud reduction is significantly and positively related to fraud investigation and detection through forensic accounting.

Emeh and Obi (2013) examined the correlations of Presence of forensic accountant, Number of accountants with forensic accounting skills and Extent of forensic accounting practices with Extent of employee theft, Extent of financial fraud and extent of top management fraud. The study utilized survey research design and the population included management staffs of selected financial institutions. A sample of one hundred and five respondents was adopted. The sampling was done using simple random sampling and data was generated using wellstructured likert scale questionnaire. The study employed the spearman rank correlation as the data analysis method. Result from the study shows there is evidence of significant negative correlations between Presence of forensic accountant, Number of accountants with forensic accounting skills and Extent of forensic accounting practices with Extent of financial fraud.

Modugu and Anyaduba (2013) examined forensic accounting and financial fraud in Nigeria. The study employed survey design with a sample size of 143 consisting of accountants, management staff, practicing auditors and stakeholders. The authors employed binomial test for data analysis and found that there is significant agreement amongst stakeholder on the effectiveness of forensic accounting in fraud control, financial reporting and internal control quality.

The work was a bit clumsy, as it stated problem and research questions together, hypotheses were stated after literature review; for a work that was said to be given an empirical approach, the structure should be better. The subject of forensic accounting was reviewed broadly, there was no specific mention of any aspect of forensic accounting being addressed.

Okoye and Gbegi (2013) carried out a study to examine forensic accounting as a tool for fraud detection and prevention in the public sector organizations with particular reference to Kogi State. The study employed simple mean and standard deviation to investigate forensic accountants to planning management fraud risk detection procedures. The study established that forensic accountants effectively modify the extent and nature of audit test when the risk of management fraud is high; and that forensic accountant should be involved in management fraud risk assessment process rather than consulting them.

The subject of forensic accounting was reviewed broadly, there was no specific mention of any aspect of forensic accounting being addressed; but very critical is their recommendation of incorporating forensic accountants in the management of the public sector rather than mere consultancy. The study did not give attention to any specific component of forensic accounting.

Omondi (2013) conducted a study on the impact of forensic accounting services on fraud detection and prevention among commercial banks in Kenya, the most prevalent type of fraud and to establish the major areas of application of forensic accounting services. The data collection instrument preferred for the study was a questionnaire. Findings from the study saw that fraud detection and prevention increased when forensic accounting services was employed. The study used descriptive research survey design and uses a sample of 47 respondents in 16 commercial banks in Kenya. The data was analyzed using Statistical package for social 
sciences (SPSS). The study findings indicated that the application of forensic accounting services by banks led to increased fraud prevention in the commercial banks and the highest application was on enhancing quality of financial reporting. The most prevalent type of fraud in the banking sector was fraudulent expense claims.

Tariq, Moayad, Sofri and Ala (2013) examined the role of forensic accounting in reducing financial corruption. This study therefore attempts to determine the impact of using forensic accounting on financial corruption. It contributes to the limited existing literature on the forensic accounting where no previous study has been down in Iraq dealing with such a serious issue. This study adopted a correlation research design. Data was collected by using interviews and questionnaires; and used Chi square and correlation analysis to analyze data collected. The main findings of the study revealed that there is a significant relationship between the forensic accounting methods and effectiveness of the control and auditing bodies to detect financial corruption cases. On the other hand, the majority of the audit and accounting personnel in Iraq are suffering from poor perception and information of the forensic accounting methods. Therefore, a suggestion was made by the current study that forensic accounting methods should add to the curricula of accounting departments in Iraqi universities at both levels of preliminary and higher studies through theoretical and practical classes

Sang, (2012) examine the determinants of fraud measures in selected commercial banks in Nakuru Town, Kenya. The objectives of the study were to assess the measures put in place at these banks to mitigate fraud and examine the effectiveness of the internal control measures on fraud occurrence. The study was based on descriptive research design. Sampling was done through stratified sampling design. Data was collected using questionnaires and analysed by using both descriptive and inferential statistics. The study concluded that the effectiveness of the internal control measures was undermined by non-adherence to dual control aspects and lack of sufficient time to undertake the various periodic tests diligently. The study recommended establishment of comprehensive fraud mitigating measures against external frauds at the cashiers departments, more enforcement of compliance of fraud mitigation methods, and lifestyle audits among the bankers to detect fraud occurrences among bankers

Zadeh and Ramazani (2012) examined accountant's perception of forensic accounting using Iran as a case study. They opined that Forensic accounting is considered as a specialized field of accounting relating frequently to legal problems (claims) and complaints. Forensic accountants usually called as forensic audits or detector accountants are bound to provide other specialists with required evidence in law counts. The study investigated the rate of accountants' perception of forensic accounting considering the fact that as accountants' perception of financial rules increases the number of firms which refer to law courts for their financial complaints will be reduced. The study used descriptive research based on Likert 5 options questionnaire to satisfy research goals. The research results indicate the low level of accountants' perception of forensic accounting methods in which the author provide some recommendations to enhance the accountants' perception of forensic accounting.

In their work, Okunbor and Obaretin (2010) examined the effectiveness of the application of forensic accounting services in Nigerian corporate organization in a sample of ten companies quoted on the Nigerian Stock Exchange by employing simple regression model for the test of hypothesis. The study showed that the application of forensic accounting services by corporate organization in Nigeria is not effective in detecting fraudulent activities. 


\section{Table 2.1 Summary of Empirical reviews}

Below is a summary of empirical reviews.

\begin{tabular}{|c|c|c|c|c|c|}
\hline $\begin{array}{l}\text { Author(s } \\
\text { ) }\end{array}$ & Title & $\begin{array}{l}\text { Coun } \\
\text { try }\end{array}$ & Variables & $\begin{array}{l}\text { Methodol } \\
\text { ogy }\end{array}$ & Findings \\
\hline $\begin{array}{l}\text { Aduwo } \\
\text { (2016) }\end{array}$ & $\begin{array}{l}\text { The role of } \\
\text { forensic } \\
\text { accounting in } \\
\text { combating the } \\
\text { menace of } \\
\text { corporate failure }\end{array}$ & $\begin{array}{l}\text { Nigeri } \\
\mathrm{a}\end{array}$ & $\begin{array}{l}\text { Forensic } \\
\text { accounting, } \\
\text { Corporate } \\
\text { failure }\end{array}$ & $\begin{array}{l}\text { Conceptu } \\
\text { al review }\end{array}$ & $\begin{array}{l}\text { The study concluded that } \\
\text { forensic auditing can go a long } \\
\text { way to influence financial } \\
\text { scandals in corporate } \\
\text { organizations }\end{array}$ \\
\hline $\begin{array}{l}\text { Eliezer } \\
\text { and } \\
\text { Emmanu } \\
\text { el (2015) }\end{array}$ & $\begin{array}{l}\text { Relevance of } \\
\text { forensic } \\
\text { accounting in } \\
\text { the detection } \\
\text { and prevention } \\
\text { of fraud in } \\
\text { Nigeria }\end{array}$ & $\begin{array}{l}\text { Nigeri } \\
\mathrm{a}\end{array}$ & $\begin{array}{l}\text { Forensic } \\
\text { accounting, } \\
\text { Fraud } \\
\text { Detection } \\
\text { and } \\
\text { Prevention }\end{array}$ & $\begin{array}{l}\text { Theoretic } \\
\text { al review }\end{array}$ & $\begin{array}{l}\text { Forensic accounting services } \\
\text { will assist audit committee } \\
\text { members in carrying out their } \\
\text { oversight functions by providing } \\
\text { assurance on internal audit } \\
\text { report. }\end{array}$ \\
\hline $\begin{array}{l}\text { Enofe, } \\
\text { Agbonkp } \\
\text { olor and } \\
\text { Edebiri } \\
(2015)\end{array}$ & $\begin{array}{l}\text { Forensic } \\
\text { accounting and } \\
\text { financial fraud }\end{array}$ & $\begin{array}{l}\text { Nigeri } \\
\text { a }\end{array}$ & $\begin{array}{l}\text { Forensic } \\
\text { accounting, } \\
\text { Financial } \\
\text { crime }\end{array}$ & $\begin{array}{l}\text { Chi- } \\
\text { square }\end{array}$ & $\begin{array}{l}\text { There is a need for forensic } \\
\text { accountants in the Nigerian } \\
\text { banking system, forensic } \\
\text { accounting is an effective tool } \\
\text { for addressing financial crimes } \\
\text { in the banking system and there } \\
\text { are significant differences } \\
\text { between the roles of forensic } \\
\text { accounting and that of } \\
\text { conventional accounting in } \\
\text { curbing financial crimes. }\end{array}$ \\
\hline $\begin{array}{l}\text { Enofe, } \\
\text { Idemudia } \\
\text { and } \\
\text { Emmanu } \\
\text { el (2015) }\end{array}$ & $\begin{array}{l}\text { Forensic } \\
\text { accounting a } \\
\text { panacea to fraud } \\
\text { reduction in } \\
\text { Nigeria firms }\end{array}$ & $\begin{array}{l}\text { Nigeri } \\
\mathrm{a}\end{array}$ & $\begin{array}{l}\text { Forensic } \\
\text { accounting, } \\
\text { Fraud } \\
\text { Reduction }\end{array}$ & $\begin{array}{l}\text { Regressio } \\
\mathrm{n} \\
\text { Analysis } \\
\text { and Chi- } \\
\text { square }\end{array}$ & $\begin{array}{l}\text { Forensic accounting enhances } \\
\text { financial fraud reduction in } \\
\text { Nigeria firms; improves control } \\
\text { systems, impact financial } \\
\text { reporting credibility and } \\
\text { transparency. }\end{array}$ \\
\hline $\begin{array}{l}\text { Enofe, } \\
\text { Utomwe } \\
\mathrm{n} \text { and } \\
\text { Danjuma } \\
(2015)\end{array}$ & $\begin{array}{l}\text { The role of } \\
\text { forensic } \\
\text { accounting in } \\
\text { mitigating } \\
\text { financial crimes }\end{array}$ & $\begin{array}{l}\text { Nigeri } \\
\mathrm{a}\end{array}$ & $\begin{array}{l}\text { Forensic } \\
\text { accounting, } \\
\text { Financial } \\
\text { crime }\end{array}$ & $\begin{array}{l}\text { Regressio } \\
\mathrm{n} \text { analysis }\end{array}$ & $\begin{array}{l}\text { There is need for forensic } \\
\text { accountants in the Nigerian } \\
\text { banking sector; Forensic } \\
\text { accounting is an effective tool } \\
\text { for addressing financial crimes } \\
\text { in the banking system }\end{array}$ \\
\hline $\begin{array}{l}\text { Oladejo } \\
\text { and } \\
\text { Oluwase } \\
\text { un (2015) }\end{array}$ & $\begin{array}{l}\text { Impact of } \\
\text { forensic } \\
\text { accounting on } \\
\text { fraud reduction } \\
\text { in Nigerian } \\
\text { banking sector } \\
\end{array}$ & $\begin{array}{l}\text { Nigeri } \\
\mathrm{a}\end{array}$ & $\begin{array}{l}\text { Forensic } \\
\text { accounting, } \\
\text { Fraud }\end{array}$ & $\begin{array}{l}\text { Descripti } \\
\text { ve } \\
\text { statistic } \\
\text { tool and } \\
\text { Chi- } \\
\text { square }\end{array}$ & $\begin{array}{l}\text { Forensic Accounting is } \\
\text { significantly useful in fraud } \\
\text { control and reduction in the } \\
\text { Nigeria Banking Industry and } \\
\text { positively influence banks } \\
\text { performance. }\end{array}$ \\
\hline
\end{tabular}




\begin{tabular}{|c|c|c|c|c|c|}
\hline $\begin{array}{l}\text { Onodi, } \\
\text { Okafor } \\
\text { and } \\
\text { Onyali } \\
(2015)\end{array}$ & $\begin{array}{l}\text { The impact of } \\
\text { forensic } \\
\text { investigative } \\
\text { method on } \\
\text { corporate fraud } \\
\text { deterrence in } \\
\text { banks in Nigeria }\end{array}$ & $\begin{array}{l}\text { Nigeri } \\
\mathrm{a}\end{array}$ & $\begin{array}{l}\text { Forensic } \\
\text { investigatio } \\
\mathrm{n}, \\
\text { Corporate } \\
\text { fraud }\end{array}$ & $\begin{array}{l}\text { Regressio } \\
\mathrm{n} \text { analysis } \\
\text { and Z- } \\
\text { test. }\end{array}$ & $\begin{array}{l}\text { There is a significant } \\
\text { relationship between the } \\
\text { forensic investigative methods } \\
\text { and corporate fraud deterrence. }\end{array}$ \\
\hline $\begin{array}{l}\text { Augustin } \\
\text { e and } \\
\text { Uagbale- } \\
\text { Ekatah } \\
(2014)\end{array}$ & $\begin{array}{l}\text { The growing } \\
\text { relevance of } \\
\text { forensic } \\
\text { accounting as a } \\
\text { tool for } \\
\text { combating fraud } \\
\text { and corruption: } \\
\text { Nigeria } \\
\text { experience }\end{array}$ & $\begin{array}{l}\text { Nigeri } \\
\mathrm{a}\end{array}$ & $\begin{array}{l}\text { Forensic } \\
\text { accounting, } \\
\text { Fraud and } \\
\text { corruption }\end{array}$ & $\begin{array}{l}\text { Descripti } \\
\text { ve } \\
\text { statistic }\end{array}$ & $\begin{array}{l}\text { The key findings of this study } \\
\text { are that: forensic accounting } \\
\text { practice is largely considered to } \\
\text { be at its infancy stage and } \\
\text { although it is relevant, yet it } \\
\text { lacking statutory support. }\end{array}$ \\
\hline $\begin{array}{l}\text { Mukoro, } \\
\text { Faboyede } \\
\text { and } \\
\text { Eziamak } \\
\text { a (2014) }\end{array}$ & $\begin{array}{l}\text { The } \\
\text { effectiveness of } \\
\text { forensic } \\
\text { accountants in } \\
\text { strengthening } \\
\text { internal control } \\
\text { of business } \\
\text { organizations in } \\
\text { Nigeria }\end{array}$ & $\begin{array}{l}\text { Nigeri } \\
\mathrm{a}\end{array}$ & \begin{tabular}{l}
\multicolumn{1}{c}{ Forensic } \\
accounting, \\
Internal \\
control
\end{tabular} & $\begin{array}{l}\text { Regressio } \\
\mathrm{n} \\
\text { Analysis. }\end{array}$ & $\begin{array}{l}\text { Internal control and its } \\
\text { components play a significant } \\
\text { role in controlling fraud in } \\
\text { business organizations. }\end{array}$ \\
\hline $\begin{array}{l}\text { Odelabu } \\
\text { (2014) }\end{array}$ & $\begin{array}{l}\text { Effect of } \\
\text { forensic } \\
\text { accounting on } \\
\text { financial } \\
\text { performance of } \\
\text { commercial } \\
\text { banks in Nigeria }\end{array}$ & $\begin{array}{l}\text { Nigeri } \\
\text { a }\end{array}$ & $\begin{array}{l}\text { Forensic } \\
\text { investigatio } \\
\mathrm{n}, \\
\text { Litigation, } \\
\text { Bank } \\
\text { performanc } \\
\mathrm{e}\end{array}$ & $\begin{array}{l}\text { Regressio } \\
\mathrm{n} \\
\text { Analysis. }\end{array}$ & $\begin{array}{l}\text { Forensic investigation and } \\
\text { forensic litigation was } \\
\text { statistically significant in } \\
\text { explaining changes in financial } \\
\text { performance of commercial } \\
\text { banks. }\end{array}$ \\
\hline $\begin{array}{l}\text { Peter, } \\
\text { Masoyi, } \\
\text { Ernest } \\
\text { and } \\
\text { Gabriel } \\
(2014)\end{array}$ & $\begin{array}{l}\text { Application of } \\
\text { forensic } \\
\text { auditing in } \\
\text { reducing fraud } \\
\text { cases in Nigeria } \\
\text { money deposit } \\
\text { banks }\end{array}$ & $\begin{array}{l}\text { Nigeri } \\
\mathrm{a}\end{array}$ & $\begin{array}{l}\text { Forensic } \\
\text { auditing, } \\
\text { Fraud } \\
\text { reduction }\end{array}$ & $\begin{array}{l}\text { Descripti } \\
\text { ve } \\
\text { analysis }\end{array}$ & $\begin{array}{l}\text { There are up and down } \\
\text { movements in fraud cases. The } \\
\text { study suggested employment of } \\
\text { forensic auditing in Nigerian } \\
\text { banks by amending the existing } \\
\text { statutes, in such a way that } \\
\text { forensic auditors are included in } \\
\text { the audit team. }\end{array}$ \\
\hline $\begin{array}{l}\text { Dada, } \\
\text { Owolabi } \\
\& \text { Okwu } \\
(2013)\end{array}$ & $\begin{array}{l}\text { Forensic } \\
\text { accounting a } \\
\text { panacea to } \\
\text { alleviation of } \\
\text { fraudulent } \\
\text { practices in } \\
\text { Nigeria }\end{array}$ & $\begin{array}{l}\text { Nigeri } \\
\mathrm{a}\end{array}$ & $\begin{array}{l}\text { Forensic } \\
\text { accounting, } \\
\text { Fraud }\end{array}$ & $\begin{array}{l}\text { Multiple } \\
\text { Regressio } \\
\mathrm{n} \\
\text { Analysis }\end{array}$ & $\begin{array}{l}\text { Fraud reduction is significantly } \\
\text { and positively related to fraud } \\
\text { investigation and detection } \\
\text { through forensic accounting. }\end{array}$ \\
\hline
\end{tabular}




\begin{tabular}{|c|c|c|c|c|c|}
\hline $\begin{array}{l}\text { Emeh } \\
\text { and Obi } \\
\text { (2013) }\end{array}$ & $\begin{array}{l}\text { An empirical } \\
\text { analysis of } \\
\text { forensic } \\
\text { accounting and } \\
\text { financial fraud } \\
\text { in Nigeria }\end{array}$ & $\begin{array}{l}\text { Nigeri } \\
\mathrm{a}\end{array}$ & $\begin{array}{l}\text { Forensic } \\
\text { accounting, } \\
\text { Financial } \\
\text { fraud }\end{array}$ & $\begin{array}{l}\text { Spearman } \\
\text { Rank } \\
\text { Correlatio } \\
\mathrm{n}\end{array}$ & $\begin{array}{l}\text { There is evidence of significant } \\
\text { negative correlations between } \\
\text { Presence of forensic accountant, } \\
\text { Number of accountants with } \\
\text { forensic accounting skills and } \\
\text { Extent of forensic accounting } \\
\text { practices with Extent of } \\
\text { financial fraud }\end{array}$ \\
\hline $\begin{array}{l}\text { Modugu } \\
\text { and } \\
\text { Anyadub } \\
\text { a (2013) }\end{array}$ & $\begin{array}{l}\text { Forensic } \\
\text { accounting and } \\
\text { financial fraud } \\
\text { in Nigeria: An } \\
\text { empirical } \\
\text { approach }\end{array}$ & $\begin{array}{l}\text { Nigeri } \\
\mathrm{a}\end{array}$ & $\begin{array}{l}\text { Forensic } \\
\text { accounting, } \\
\text { Financial } \\
\text { fraud, } \\
\text { Financial } \\
\text { reporting } \\
\text { quality, } \\
\text { Internal } \\
\text { control }\end{array}$ & $\begin{array}{l}\text { Binomial } \\
\text { test for } \\
\text { data } \\
\text { analysis }\end{array}$ & $\begin{array}{l}\text { There is significance agreement } \\
\text { amongst stakeholder on the } \\
\text { effectiveness of forensic } \\
\text { accounting in fraud control, } \\
\text { financial reporting and internal } \\
\text { control quality. }\end{array}$ \\
\hline $\begin{array}{l}\text { Okoye } \\
\text { and } \\
\text { Gbegi } \\
\text { (2013) }\end{array}$ & $\begin{array}{l}\text { Forensic } \\
\text { accounting: A } \\
\text { tool for fraud } \\
\text { detection and } \\
\text { prevention in } \\
\text { the public sector }\end{array}$ & $\begin{array}{l}\text { Nigeri } \\
\mathrm{a}\end{array}$ & $\begin{array}{l}\text { Forensic } \\
\text { accounting, } \\
\text { Fraud } \\
\text { detection } \\
\text { and } \\
\text { prevention }\end{array}$ & $\begin{array}{l}\text { Standard } \\
\text { deviation } \\
\text { and } \\
\text { ANOVA }\end{array}$ & $\begin{array}{l}\text { Forensic accountants effectively } \\
\text { modify the extent and nature of } \\
\text { audit test when the risk of } \\
\text { management fraud is high; and } \\
\text { that forensic accountant should } \\
\text { be involved in management } \\
\text { fraud risk assessment process } \\
\text { rather than consulting them. }\end{array}$ \\
\hline $\begin{array}{l}\text { Omondi } \\
\text { (2013) }\end{array}$ & $\begin{array}{l}\text { The impact of } \\
\text { forensic } \\
\text { accounting } \\
\text { services on } \\
\text { fraud detection } \\
\text { and prevention } \\
\text { among } \\
\text { commercial } \\
\text { banks in Kenya }\end{array}$ & Kenya & $\begin{array}{l}\text { Forensic } \\
\text { accounting } \\
\text { services, } \\
\text { Fraud } \\
\text { detection } \\
\text { and } \\
\text { prevention }\end{array}$ & $\begin{array}{l}\text { Regressio } \\
\mathrm{n} \\
\text { Analysis. }\end{array}$ & $\begin{array}{l}\text { Application of forensic } \\
\text { accounting services by banks led } \\
\text { to increased fraud prevention in } \\
\text { the commercial banks and the } \\
\text { highest application was on } \\
\text { enhancing quality of financial } \\
\text { reporting. The most prevalent } \\
\text { type of fraud in the banking } \\
\text { sector was fraudulent expense } \\
\text { claims. }\end{array}$ \\
\hline $\begin{array}{l}\text { Tariq, } \\
\text { Moayad, } \\
\text { Sofri and } \\
\text { Ala } \\
\text { (2013) }\end{array}$ & $\begin{array}{l}\text { The Role of } \\
\text { Forensic } \\
\text { Accounting in } \\
\text { Reducing } \\
\text { Financial } \\
\text { Corruption: A } \\
\text { Study in Iraq. }\end{array}$ & Iraq & $\begin{array}{l}\text { Forensic } \\
\text { accounting, } \\
\text { Financial } \\
\text { corruption }\end{array}$ & $\begin{array}{l}\text { Chi } \\
\text { square } \\
\text { and } \\
\text { correlatio } \\
\text { n analysis }\end{array}$ & $\begin{array}{l}\text { There is a significant } \\
\text { relationship between the } \\
\text { forensic accounting methods and } \\
\text { effectiveness of the control and } \\
\text { auditing bodies to detect } \\
\text { financial corruption cases. The } \\
\text { study recommend that forensic } \\
\text { accounting methods should add } \\
\text { to the curricula of accounting } \\
\text { departments in Iraqi universities } \\
\text { through theoretical and practical } \\
\text { classes }\end{array}$ \\
\hline
\end{tabular}




\begin{tabular}{|c|c|c|c|c|c|}
\hline $\begin{array}{l}\text { Sang, } \\
\text { (2012) }\end{array}$ & $\begin{array}{l}\text { Determinants of } \\
\text { fraud control } \\
\text { measures in } \\
\text { commercial } \\
\text { banks: A Survey } \\
\text { of selected } \\
\text { commercial } \\
\text { banks in Nakuru } \\
\text { Town, Kenya. }\end{array}$ & Kenya & & $\begin{array}{l}\text { Descripti } \\
\text { ve and } \\
\text { Inferentia } \\
\text { 1 statistics }\end{array}$ & $\begin{array}{l}\text { Effectiveness of the internal } \\
\text { control measures was } \\
\text { undermined by non-adherence to } \\
\text { dual control aspects. The study } \\
\text { recommended establishment of } \\
\text { comprehensive fraud mitigating } \\
\text { measures against external frauds } \\
\text { at the cashiers departments, } \\
\text { more enforcement of } \\
\text { compliance of fraud mitigation } \\
\text { methods }\end{array}$ \\
\hline $\begin{array}{l}\text { Zadeh } \\
\text { and } \\
\text { Ramazan } \\
\text { i (2012) }\end{array}$ & $\begin{array}{l}\text { Accountant's } \\
\text { perception of } \\
\text { forensic } \\
\text { accounting (case } \\
\text { study of Iran). }\end{array}$ & Iran & $\begin{array}{l}\text { Forensic } \\
\text { accounting }\end{array}$ & $\begin{array}{l}\text { Descripti } \\
\text { ve } \\
\text { statistics }\end{array}$ & $\begin{array}{l}\text { The research results indicate the } \\
\text { low level of accountants' } \\
\text { perception of forensic } \\
\text { accounting methods in which } \\
\text { the author provide some } \\
\text { recommendations to enhance the } \\
\text { accountants' perception of } \\
\text { forensic accounting }\end{array}$ \\
\hline $\begin{array}{l}\text { Okunbor } \\
\text { and } \\
\text { Obaretin } \\
(2010)\end{array}$ & $\begin{array}{l}\text { Effectiveness of } \\
\text { the application } \\
\text { of forensic } \\
\text { accounting } \\
\text { services in } \\
\text { Nigerian } \\
\text { corporate } \\
\text { organizations }\end{array}$ & $\begin{array}{l}\text { Nigeri } \\
\mathrm{a}\end{array}$ & $\begin{array}{l}\text { Forensic } \\
\text { accounting } \\
\text { services }\end{array}$ & $\begin{array}{l}\text { Simple } \\
\text { Regressio } \\
\text { n Model }\end{array}$ & $\begin{array}{l}\text { The application of forensic } \\
\text { accounting services by corporate } \\
\text { organization in Nigeria is not } \\
\text { effective in determine fraudulent } \\
\text { activities. }\end{array}$ \\
\hline
\end{tabular}

Source: Summary of Researcher's empirical review.

\section{Gap in Literature}

As fraud cannot be said to be totally eradicated, deploying appropriate measures/techniques to curb the menace is a vital to the going concern of any organization, be it small or large; without which you have succeeded in opening it up to fraudulent practices, and might ultimately lead to the failure of such an organization. This was evident in the occurrences in the Nigerian banking sector about a decade ago, that lead to the collapse of some banks and the regrouping of other. With the advancement in technology, banks in recent times are seeking easier and cheaper ways to do business and therefore are embracing more sophisticated software applications.

Drawing from the above empirical reviews it could be concluded that; quite a number of studies exist on the subject of forensic accounting, fraud and financial crime. Existing empirical evidence also point to the fact that forensic accounting was studied broadly without emphasis on what the forensic accountants/auditors does in terms of their responsibilities in detecting fraud. Considering that fraudulent practices are assuming new dimensions as the methods of doing banking business are changing with advancement in technology, there is need to validate the effectiveness of the components of forensic accounting services in tackling the risk that 
come with the changes. This study is therefore relevant, as it seeks to assess the impact of forensic accounting components of conducting investigation, analyzing financial transactions and reconstructing incomplete accounting records in detecting fraud and fraudulent practices in deposit money banks in Nigeria.

\section{RESEARCH METHODOLOGY}

\section{Research Design}

This study adopted the survey research design. The choice of this design was anchored on fact that survey research design is one that focuses on a definite person(s), group(s), organization or issue(s). Survey research allow the collection of a large amount of data from a sizeable population in an economical way. It is a design that tend to identify and describe the basic and specific characteristics, features and peculiarities on the study group, for which inferences may be drawn, a set of action may be taken or utilize the identified state of things depending on the objectives of the research.

\section{Population of the Study}

The population of the study comprises of 1305 internal control staff from the ten (10) deposit money banks (DMBs) in Nigeria with international authorization as categorized by the Central Bank of Nigeria (CBN) as at May 25, 2016. This category of DMBs were chosen on the premise that they interact with other stakeholders both locally and internationally hence they are likely to face more sophisticated fraudulent activities and therefore be in a much better position to provide the relevant responses to the research questions

\section{Sample Size}

This study used purposive sampling technique to select it sample size. The choice of the technique is premised on its defining feature of allowing selection of sample on purpose or based on the judgment of the researcher. To this end, the sample of this study was one hundred (100) internal control staff purposively drawn from the ten deposit money banks licensed with international authorization operating in Nigerian banking sector.

\section{Sources of Data}

For the purpose of this study, the researcher sourced for data from primary source. Primary source of data involves collecting data from original sources, which is first hand data. 'Primary data was collected from internal control, audit and compliance staff from the Ten (10) deposit money banks license with international authorization operating in Nigerian banking sector through well-structured Likert scale questionnaire.

\section{Questionnaire}

To enable effective computation of the data, the responses gotten from the Likert scale questionnaires were assigned numeric values in the following form and rank: Strongly agree (5), Agree (4), Undecided (3), Disagree (2) and Strongly Disagree (1); this is further summarized in a tabular for 


\begin{tabular}{|c|c|c|c|c|c|}
\hline Likert Scale & Strongly Agree & Agree & Undecided & Disagree & Strongly Disagree \\
\hline Assigned values & $\mathbf{5}$ & 4 & $\mathbf{3}$ & $\mathbf{2}$ & $\mathbf{1}$ \\
\hline
\end{tabular}

The questionnaires were administered to the respondents and retrieved from same within the first quarter of 2018.

\section{Data Validity and Reliability}

To ensure validity of the questionnaire used for the study, the questionnaire (draft form) was presented to researchers in selected institutions for their independent review on its fact, standard and content. Based on their comments and suggestions, necessary adjustments were done on the draft questionnaire.

To verify the reliability of the instrument (questionnaire) developed for the purpose of this study, the research used Cronbach's Alpha. The value of Cronbach's Alpha, measured by SPSS software, is $0.88>0.70$ which indicates the reliability of the test and describes the validity of the responses. In order to examine the proposition one week test reliability, 10 questionnaires were sent again to those addresses the results indicated the uniform responses during a week which show the reliability of the questions.

Table 3.1: Reliability Statistics

\begin{tabular}{|c|c|}
\hline Cronbach's Alpha & No. of Items \\
\hline 0.856 & 15 \\
\hline
\end{tabular}

Source: SPSS 2.0

\section{Techniques of Data Analysis}

The data collected was processed both manually and electronically using Statistical Packages for Social Sciences (SPSS). The statistical tool used in the analysis of the data collected was Descriptive Statistics and Regression Analysis.

\section{Descriptive Statistics}

Descriptive statistics of Mean and standard deviation was used to analyze data collected. Data relating to research questions were analyzed using mean scores and standard deviation from the Likert scale. A mean of 3.0 and above indicate a positive response, which is Accept; any statement of mean below 3.0 is negative response, which is Reject.

\section{Regression Analysis}

Regression analysis is a causal or impact measuring statistic. Regression method employs a statistical equation to predict the value of a numerical dependent (or response) variable from the known value(s) of at least one numerical independent (or explanatory) variable (Akpa, 
2011). That is, it is used to determine the effect of an independent variable on a dependent variable.

The equation of the line is the regression equation which provides estimates of the dependent variables when those of the independent variables are inserted into the equation. What is of interest in linear regression is obtaining a straight line that best fits the data in such a way as to closely approximate the relationship between the dependent and the independent variables.

\section{T-Statistic}

The t-statistic was used to test the research hypothesis that were formulated earlier in chapter one. The level of significance chosen for this research is $5 \%$ for a two tailed test and at a critical value of $t+1.96$ and a region of non-rejection as -1.96 and +1.96 was used. The decision rule is to accept the null hypothesis if the calculated value of the statistic falls in the region of nonrejection.

\section{Variables Identification and Model Specification}

\section{Variables Identification}

The study used financial fraud detection as the dependent variable, Conducting investigation, Analyzing financial transactions, and Reconstructing incomplete accounting records as the independent variables.

\section{Model Specification}

The study model is based on the impact of forensic accounting on financial fraud detection in deposit money banks in Nigeria. The study posited that financial fraud detection in deposit money banks is a function of a mix of forensic accounting activities.

The model of this relationship is presented in equation one below;

Financial fraud detection $=f$ (Conducting investigation, Analyzing financial transactions, Reconstructing incomplete accounting records).

\section{Analytical model}

The multiple regression model was used to examine the relationship between the variables; that is financial fraud detection and components of forensic accounting. This model is in line with the work of Omondi (2013) and Chi-chi and Ebimobowei (2011); the model was adopted with some modifications made.

Algebraic expression of the analytical model is presented in equation two below.

Fraud detection $=\beta_{0}+\beta_{1}($ Conducting investigation $)+\beta_{2}$ (Analyzing financial transactions $)+$ $\beta_{3}$ (Reconstructing incomplete accounting records) $+\mu$.

$\mathrm{FD}=\beta_{0}+\beta_{1}(\mathrm{CI})+\beta_{2}(\mathrm{AF})+\beta_{3}(\mathrm{RA})+\mu$

FD - Financial Fraud detection

$\mathrm{CI}-$ Conducting investigation 
$\mathrm{AF}$ - Analyzing financial transactions

RA - Reconstructing incomplete accounting records

$\mu$ - An error term of the model

Where $\beta_{0}$ is the constant of the model while $\beta_{1}, \beta_{2}$ and $\beta_{3}$ are the coefficients of the independent variables.

The role of conducting investigation, analyzing financial transaction and reconstruction of incomplete accounting record in fraud detection was measured based on their indices from the responses that was derived from the Likert scale questionnaire.

\section{Decision Rule}

The hypothesis was tested at $5 \%$ level of significance for a two tailed test and at a critical value of $t+1.96$ and a region of non-rejection as -1.96 and +1.96 was used. The decision rule is to accept the null hypothesis if the calculated value of the statistic falls in the region of nonrejection or the calculated probability value is above the significant value of $5 \%$.

A significance level lower than or equal to 0.05 shows that the model used for the study is fit and can lead to the generalization of better result. However, if this value is more than 0.05 , it shows that the model is not fit to generate a good and convincing result and should be modified or discarded.

\section{DATA PRESENTATION, ANALYSIS AND RESULTS}

\section{Data Presentation and Analysis}

In this section the data collected using the questionnaires are presented analyzed in a summarized format.

\section{Descriptive Statistics}

The descriptive statistics for the variables are presented in tables below:

\section{Table 4.1: Questionnaire}

\begin{tabular}{lrr}
\hline Questionnaire & Frequency & \multicolumn{1}{c}{$(\boldsymbol{\%})$} \\
\hline Returned & 87 & 87 \\
Not Returned & 13 & 13 \\
TOTAL & $\mathbf{1 0 0}$ & $\mathbf{1 0 0}$
\end{tabular}

Source: Field survey, 2018 
Table 4.1 shows the frequency distribution of questionnaires administered. A total number of $100(100 \%)$ copies of questionnaire were administered to the sampled respondents. However, out of this number, it was $87(87 \%)$ questionnaire that were returned and found usable while $13(13 \%)$ of the questionnaire were not returned. The data collected using the questionnaires are as presented in the tales below:

Table 4.2: Does your bank have a forensic unit/fraud management desk

\begin{tabular}{|l|l|l|}
\hline & Frequency & $\mathbf{( \% )}$ \\
\hline Yes & 87 & 100 \\
\hline No & 0 & 0 \\
\hline TOTAL & $\mathbf{8 7}$ & $\mathbf{1 0 0}$ \\
\hline
\end{tabular}

Source: Field Survey, 2018

Table 4.2 shows if sampled deposit money banks had forensic unit/fraud management desk. The results reveals that 87 of 87 respondents representing $100 \%$ of the sampled banks agreed that their bank have forensic unit/fraud management desk. This shows that forensic accounting is a tool for financial fraud detection in Deposit Money Banks in Nigeria.

Table 4.3: Does your bank actively apply forensic accounting services

\begin{tabular}{|l|l|l|}
\hline & Frequency & $(\boldsymbol{\%})$ \\
\hline Yes & 87 & 100 \\
\hline No & 0 & 0 \\
\hline TOTAL & $\mathbf{8 7}$ & $\mathbf{1 0 0}$ \\
\hline
\end{tabular}

Source: Field Survey, 2018

Table 4.3 shows if sampled deposit money banks actively apply forensic accounting services. The results reveals that 87 of 87 respondents representing $100 \%$ of the sampled banks agreed that their bank actively apply forensic accounting services. This shows that forensic accounting services are relevant to the operations of Deposit Money Banks.

Table 4.4: Is the scope of forensic accounting work in your bank sufficient to detect financial fraud

\begin{tabular}{|l|l|l|}
\hline & Frequency & $\mathbf{( \% )}$ \\
\hline Yes & 87 & 100 \\
\hline No & 0 & 0 \\
\hline TOTAL & $\mathbf{8 7}$ & $\mathbf{1 0 0}$ \\
\hline
\end{tabular}

Source: field survey, 2018 
Table 4.4 shows if the scope of forensic accounting work in sampled deposit money banks is sufficient to detect financial fraud. The results reveals that 87 of 87 respondents representing $100 \%$ of the sampled banks agreed that the scope of forensic accounting work in their bank is sufficient to detect financial fraud. This shows that forensic accounting services is adequately harnessed can be a vital for financial fraud detection in Deposit Money Banks in Nigeria.

\section{SECTION A: Financial Fraud Detection}

Table 4.5: Financial Fraud Detection

\begin{tabular}{|l|l|c|}
\hline & Mean & STD \\
\hline $\begin{array}{l}\text { Financial fraud is not easily detected, except with appropriate skills and } \\
\text { training }\end{array}$ & 4.26 & 0.637 \\
\hline $\begin{array}{l}\text { A collaborative and efficient approach is essential to detect fraudulent } \\
\text { financial activities }\end{array}$ & 4.44 & 0.642 \\
\hline $\begin{array}{l}\text { The deployment of an industry system antifraud solution will greatly } \\
\text { tackle financial fraud }\end{array}$ & 4.31 & 0.616 \\
\hline AVERAGE & $\mathbf{4 . 3 7}$ & $\mathbf{0 . 6 3 2}$ \\
\hline
\end{tabular}

Source: Field survey, 2018

Table 4.5 shows the respondents' view on financial fraud detection. The result reveals that financial fraud detection require appropriate skills and training with mean score of 4.26 , a collaborative and efficient approach is essential to detect fraudulent activities had a mean score of 4.44. While, the deployment of an industry antifraud solution will greatly tackle financial fraud with mean score of 4.31; with the overall average mean score of 4.37 .

A collaborative and efficient approach is essential to detect fraudulent activities with mean score of 4.44 proves the motive behind seeking to validate the effectiveness of forensic accounting in financial fraud detection.

The table also shows the standard deviation among the respondents' view. The deviation among the respondents' opinion is between 0.616 and 0.642 with overall difference of 0.632 . The standard deviations of the responses have also indicated very low values implying that, the responses are not widely varied. 
SECTION B: Conducting Investigation as a forensic accounting technique.

\section{Research Question 1: Conducting investigations is effective in financial fraud detection in DMBs in Nigeria}

Table 4.6: Conducting Investigation

\begin{tabular}{|l|l|c|}
\hline & Mean & STD \\
\hline $\begin{array}{l}\text { Forensic accounting investigation techniques is robust in probing and } \\
\text { revealing suspicious financial transactions }\end{array}$ & 4.29 & 0.627 \\
\hline $\begin{array}{l}\text { Forensic accounting investigations techniques detect and uncover } \\
\text { financial fraud and fraudulent activities }\end{array}$ & 4.60 & 0.493 \\
\hline $\begin{array}{l}\text { Misappropriated funds/assets and reversible insider transactions are } \\
\text { identified through forensic accounting investigations. }\end{array}$ & 4.23 & 0.623 \\
\hline $\begin{array}{l}\text { Electronic evidence discovery is performed by forensic accountants in } \\
\text { conducting investigation }\end{array}$ & 4.17 & 0.750 \\
\hline AVERAGE & $\mathbf{4 . 3 2}$ & $\mathbf{0 . 6 2 3}$ \\
\hline
\end{tabular}

Source: Field survey, 2018

Table 4.6 shows the respondents' view on conducting investigation as a forensic accounting technique for financial fraud detection. The result shows that forensic accounting investigation techniques is robust in probing and revealing suspicious financial transactions with mean 4.29, forensic accounting investigations techniques detect and uncover financial fraud and fraudulent activities with mean score of 4.60, misappropriated funds/assets and reversible insider transactions are identified through forensic accounting investigations with mean score of 4.23. While, in conducting investigation, forensic accountants perform electronic evidence discovery with mean score of 4.17. And overall mean score of 4.32.

However, forensic accounting investigations techniques detect and uncover financial fraud and fraudulent activities with mean score of 4.60 has shown that conducting investigation is an effective method for financial fraud detection.

The table also shows the standard deviation of the degree of response of the sampled population. This variation ranges from 0.493 to 0.750 with an average of 0.623 . The result shows low variation value indicating responses are not widely varied. 
SECTION C: Analyzing Financial Transactions as a forensic accounting technique.

\section{Research Question 2: Analyzing financial transactions is effective in financial fraud detection in DMBs in Nigeria.}

\section{Table 4.7: Analyzing Financial Transactions}

\begin{tabular}{|l|l|c|}
\hline & Mean & STD \\
\hline $\begin{array}{l}\text { Analyzing in a real time mode financial transaction records by forensic } \\
\text { accountants assist detect potential fraud incidence }\end{array}$ & 4.30 & 0.701 \\
\hline $\begin{array}{l}\text { Analyzing financial transactions to determine their risk level is a core } \\
\text { technique in forensic accounting }\end{array}$ & 4.31 & 0.634 \\
\hline $\begin{array}{l}\text { Forensic accounting risk assessment processes cover risk of fraud and } \\
\text { identifies red flags }\end{array}$ & 4.21 & 0.780 \\
\hline $\begin{array}{l}\text { Analysis to note abnormal rate of transactions during a period of time or } \\
\text { from a particular place is useful for financial fraud detection }\end{array}$ & 4.45 & 0.678 \\
\hline AVERAGE & $\mathbf{4 . 3 2}$ & $\mathbf{0 . 6 9 8}$ \\
\hline
\end{tabular}

Source: field survey, 2018

Table 4.7 shows the mean and standard deviation of analyzing financial transactions as a technique of forensic accounting for financial fraud detection. The findings reveals 4.30 mean score for analyzing in a real time mode financial transaction records assist detect potential fraud incidence, mean score of 4.31 for analyzing financial transactions to determine their risk level is a core technique in forensic accounting, forensic accounting risk assessment processes cover risk of fraud and identifies red flags with mean score of 4.21 . While, analysis by forensic accountants to note abnormal rate of transactions during a period or from a particular place is useful for financial fraud detection with a mean score of 4.45. Overall average mean score of 4.32 .

This reveals that, with mean of 4.45 financial transaction analysis is a useful technique for financial fraud detection.

The differences in the degree of responses of the respondents' ranges from 0.634 to 0.780 with average variation of 0.698 indicating low difference in responses of the respondents. 


\section{SECTION D: Reconstructing Incomplete Accounting Records as a forensic accounting technique.}

\section{Research Question 3: Reconstructing incomplete accounting records is effective in detecting financial fraud in DMBs in Nigeria.}

Table 4.8: Reconstruction of Incomplete Accounting Records

\begin{tabular}{|l|l|l|}
\hline & Mean & STD \\
\hline $\begin{array}{l}\text { Incidence of money laundering activities can be unveil by reconstructing } \\
\text { cash transactions }\end{array}$ & 4.09 & 0.816 \\
\hline $\begin{array}{l}\text { Creative accounting can be eliminated with forensic accounting } \\
\text { techniques by reviewing source documents }\end{array}$ & 3.93 & 0.873 \\
\hline $\begin{array}{l}\text { While reconstructing incomplete accounting records, forensic } \\
\text { accountants can unearth massive financial fraud capable of collapsing an } \\
\text { organization }\end{array}$ & 4.21 & 0.649 \\
\hline $\begin{array}{l}\text { Lack of transparency can be eliminated with forensic accountants } \\
\text { reorganizing banks financial transactions and records }\end{array}$ & 4.18 & 0.656 \\
\hline AVERAGE & $\mathbf{4 . 1 0}$ & $\mathbf{0 . 7 4 9}$ \\
\hline
\end{tabular}

Source: field survey, 2018

Table 4.8 above shows the respondents view on reconstruction of incomplete accounting records as a technique for financial fraud detection. This shows incidence of money laundering can be unveiled by reconstructing cash transactions with means score of 4.09, Creative accounting can be eliminated with forensic accounting techniques by reviewing source documents with 3.93 mean score, While reconstructing incomplete accounting records, forensic accountants can unearth massive financial fraud capable of collapsing an organization with mean score of 4.21, Lack of transparency can be eliminated with forensic accountants reorganizing banks financial transactions and records mean score of 4.18. With overall average mean score of 4.10 .

This shows that, with the technique of reconstructing incomplete accounting records, forensic accountants can detect massive financial fraud capable of collapsing an organization.

The standard deviation of the view on the subject matter varies from 0.649 to 0.873 with an average of 0.749 indicating low variation in responses of the sampled population.

\section{Regression Analysis}

The regression results are used to analyze the effects of the independent variables on the dependent variable. The statistical significance of the coefficients of the variables under consideration is treated under tests of hypotheses. In the regression analysis for testing the hypotheses, we conducted analysis of the responses for the dependent variable which is financial fraud detection (Section A Question 2) and the independent variables; conducting investigation (Section B Question 2), Analyzing financial transactions (Section C Question 4) and Reconstruction of Incomplete accounting records (Section D Question 3). 
Table 4.9: Regression Summary for Model

\begin{tabular}{|l|r|r|r|r|r|}
\hline Model & R & \multicolumn{1}{|c|}{ R Square } & Adjusted R Square & F & \multicolumn{1}{c|}{ Sig. } \\
\hline 1 & $.440^{\mathrm{a}}$ & .193 & .164 & 6.629 & $.000^{\mathrm{b}}$ \\
\hline
\end{tabular}

a. Dependent Variable: financial fraud detection

b. Predictors: (Constant), conducting investigation, analyzing

financial transactions, reconstruction of incomplete accounting records

Source: Researcher's Computations from SPSS version 20

The regression analysis for the relationship of the study employs fraud detection as its dependent variable whereas conducting investigation, analyzing financial transactions and reconstruction of incomplete accounting records, which are techniques of forensic accounting as independent variables. The summary of the model is predicated by the $\mathrm{R}$ squared and the adjusted $\mathrm{R}$ squared. The $\mathrm{R}$ squared is the predictive power of the model. It explains the proportion of the changes in the dependent variable that are being accounted for by the independent variables. In the model, the coefficient of determination (R) stood at 0.440 which means the strength of the relationship between the dependent and independent variables is moderate. The coefficient of determination $\left(\mathrm{R}^{2}\right)$ stood at $19.3 \%$. This connotes that only $19.3 \%$ of the variations in financial fraud detection in Deposit Money Banks in Nigeria consideration is explained by the independent variables while the remaining $80.7 \%$ is accounted for by factors not included in the model. This means that the factors captured in the model explain only a small proportion of the variations in financial fraud detection in Deposit Money Banks in Nigeria. The adjusted $\mathrm{R}^{2}$ of $16.4 \%$ indicates that if the entire population is considered, the independent variables will jointly account for the variations in the dependent variable by $16.4 \%$ positively. The F-statistic value is well above zero (6.629) with a probability value less than 0.0001 which is significant at $1 \%, 5 \%$ and $10 \%$. This implies that the model has a good fit. This means that the explanatory variables are jointly significant at influencing the behavior of the dependent variable.

\section{Regression Coefficients}

This section analyzes the individual effects of the independent variables on the dependent variables as captured in the model estimated in the study. 
Table 4.12: Regression Coefficients for Model above

\section{Coefficients $^{\mathrm{a}}$}

\begin{tabular}{|c|c|c|c|c|c|c|}
\hline \multirow{2}{*}{\multicolumn{2}{|c|}{ Model }} & \multicolumn{2}{|c|}{$\begin{array}{l}\text { Unstandardized } \\
\text { Coefficients }\end{array}$} & \multirow{2}{*}{$\begin{array}{c}\text { Standardized } \\
\text { Coefficients }\end{array}$} & \multirow[b]{2}{*}{$\mathrm{T}$} & \multirow[b]{2}{*}{ Sig. } \\
\hline & & $\mathrm{B}$ & Std. Error & & & \\
\hline \multirow[t]{4}{*}{1} & (Constant) & 1.209 & .756 & & 1.600 & .114 \\
\hline & Conducting Investigation & .270 & .131 & .207 & 2.060 & .043 \\
\hline & $\begin{array}{l}\text { Analysing financial } \\
\text { transaction }\end{array}$ & .242 & .096 & .256 & 2.535 & .013 \\
\hline & $\begin{array}{l}\text { Reconstruction of } \\
\text { Incomp. Acct. Records }\end{array}$ & .216 & .098 & .219 & 2.209 & .030 \\
\hline
\end{tabular}

a. Dependent Variable: Fraud detection

b. Predictors: (Constant), conducting investigation, analyzing financial transactions, reconstruction of incomplete accounting records

Source: Researcher's Computations from SPSS version 20.

The constant (intercept) term is 1.209 indicating that if any of the independent variables conducting investigation, analyzing financial transaction and reconstruction of incomplete accounting records are held constant, financial fraud detection will rise by $0.270,0.242$ and 0.216 respectively. The coefficient of conducting Investigation is positive $(0.270)$ and it is statistically significant. The magnitude of the coefficient indicates that a percentage change in conducting investigation will result to a positive change in financial fraud detection by $27.0 \%$. This means that there exists a positive relationship between financial fraud detection and conducting Investigation in DMBs. This relationship indicates that if financial institutions increase their investigation activities, other things being equal, there will a significant increase in financial fraud detection.

The coefficient of analyzing financial transaction is positive $(0.242)$ as expected and is statistically significant at $5 \%$ level of significance (given the probability value of 0.013 ). The magnitude of the coefficient reveals that a percent increase in analyzing financial transaction will increase the level of financial fraud detection in DMBs in Nigeria by $24.2 \%$. This relationship indicates that increase in Analyzing financial transaction lead to increase in financial fraud detection in Nigeria Deposit Money Banks.

The coefficient of reconstruction of incomplete accounting records is positive (0.216) and is statistically significant at $5 \%$ level of significance (given the probability value of 0.030 ). The implication of this is that increase in reconstruction of incomplete accounting records will amount to increase in detecting financial fraud.

\section{Test of Research Hypotheses}

In this section, the earlier stated prepositions in chapter one of this work were subjected to empirical testing drawing from the results of the descriptive and inferential statistical analyses. The level of significance chosen for this research is $5 \%$ for a two tailed test and at a critical value of $t+1.96$ and a region of non-rejection as -1.96 and +1.96 was used. The decision rule is to accept the null hypothesis if the calculated value of the statistic falls in the region of non- 
rejection; and if outside of the region, reject the null hypothesis and accept the alternative hypothesis. On the other hand, the null hypothesis will be rejected if the probability values of the parameter estimates are greater than the 0.05 critical value. This analysis considered both the $t$ and probability values for the test of hypotheses.

\section{Hypothesis One}

Hol: Conducting investigation has no significant effect with regards to financial fraud detection in DMBs in Nigeria

From the regression results, the t-value of the coefficient of conducting investigation with financial fraud detection as dependent variable is 2.060 which is outside the region of nonrejection of -1.96 and +1.96 . This shows that the null hypothesis can be rejected, indicating that conducting investigation has a significant effective on financial fraud detection in DMBs in Nigeria. Similarly probability value of the coefficient of conducting investigation is 0.043 which is less than 0.05 critical value.

\section{Hypothesis Two}

Ho2: Analyzing financial transactions has no significant effective on financial fraud detection in DMBs in Nigeria

The t-value of the coefficient of analyzing financial transactions as a forensic accounting technique for financial fraud detection is 2.535 which is outside the region of non-rejection of -1.96 and +1.96 . This shows that the null hypothesis can be rejected, indicating that analyzing financial transactions has a significant effective on financial fraud detection in DMBs in Nigeria. Similarly probability value of the coefficient of analyzing financial transactions is 0.013 which is less than 0.05 critical value.

\section{Hypothesis Three}

Ho3: Reconstructing incomplete accounting records has no significant effect in detecting financial fraud in DMBs in Nigeria

From the regression results, the t-value of the coefficient of reconstructing incomplete accounting records as a forensic accounting technique for detecting financial fraud is 2.209 which is outside the region of non-rejection of -1.96 and +1.96 . In like manner, probability value of the coefficient of reconstructing incomplete accounting records is 0.030 which is less than 0.05 critical value. Given the decision rule earlier stated, the null hypothesis is rejected. This implies that the alternative hypothesis was accepted; meaning that reconstructing incomplete accounting records significantly help in detecting financial fraud in DMBs in Nigeria. 


\section{DISCUSSION OF FINDINGS}

This section discusses the findings of the study in line with the research objectives.

Objective One: To examine the effectiveness of conducting investigation on financial fraud detection in DMBs in Nigeria

The study found that conducting investigation has a positive and significant effect on financial fraud detection in DMBs in Nigeria. This is shows that, forensic accounting investigation can be used to detect fraud, unearth hidden fraudulent activities and probing suspicious financial transactions. This finding is in line with the finding of Onodi, Okafor and Onyali (2015) who found that there is a significant relationship between the forensic investigative methods and corporate fraud deterrence.

Objective Two: To ascertain the effectiveness of analyzing financial transactions on financial fraud detection in DMBs in Nigeria

The study found that analyzing financial transactions has a positive and significant effect on financial fraud detection in DMBs operations. This shows that, financial transaction analysis is a useful technique for financial fraud detection in deposit money banks in Nigeria. Therefore, it can be said that the technique is capable of detecting suspicious and fraudulent activities.

Objective Three: To establish that reconstructing incomplete accounting records can be effective in detecting financial fraud in DMBs in Nigeria

The study reveals that reconstructing incomplete accounting records has a positive and significant effect in detecting financial fraud in DMBs. This implies that, forensic accountants can detect colossal financial fraud capable of collapsing the bank from just a piece of information by reconstructing incomplete accounting records. Therefore it can be said that with slight information on transactions, employing the technique of reconstruction of incomplete accounting records, forensic accountants can unearth massive fraudulent activities.

\section{SUMMARY, CONCLUSION AND RECOMMENDATIONS}

\section{Summary of the Findings}

Advancement in technology brought massive innovation in the way and manner banking operations are done in recent times; as the banking operations advanced with technology so also did fraud and fraudulent activities. The importance of putting in place adequate techniques for detecting and preventing fraud in an organization cannot be overemphasis, this among other things lead to the use of forensic accounting techniques in combating fraud in the banking sector. The study examines the impact of forensic accounting on fraud detection in deposit money banks in Nigeria and used survey research design. Below are principal finding from the study:

1. Conducting investigation has a positive and significant effect on financial fraud detection in deposit money banks in Nigeria. 
2. Analyzing financial transactions has a positive and significant effect on financial fraud detection in deposit money banks in Nigeria.

3. Reconstruction of incomplete accounting records has a positive and significant effect in detecting financial fraud in deposit money banks in Nigeria.

\section{Conclusion}

Bank operations over the years have changed drastically majorly due to developments in the field of information and communication technology. These developments also changed the way fraud and fraudulent activities are perpetuated, and the effect on banking operations. The concerns of stakeholders across all organizations is to seek ways to combat these sophisticated fraudulent activities. The essence of all the measure that organizations adopt is to ensure smoothness of activities, avoid errors (intention and unintentional), detect and prevent fraud and fraudulent practices and discourage those with such intentions.

The study examined the impact of forensic accounting on fraud detection in deposit money banks in Nigeria. The study considered the various components of forensic accounting in relation to fraud detection. Judging from the findings of the research, the researcher concluded that forensic accounting has a positive and significant impact on fraud detection in deposit money banks in Nigeria. Conclusively, it can therefore be said that:

1. Conducting investigation as a component of forensic accounting is effective in detecting fraud and fraudulent activities

2. Forensic accounting component of Analyzing financial transactions is significant in fraud detection.

3. Reconstructing incomplete accounting records as a forensic accounting component is effective in detecting fraud.

\section{Recommendations}

In view of the rapid development in information and communication technology that is changing banks mode of operations and bringing innovations to banking, and even the method fraudsters operate as well as the likely effects of their activities on the banks and customers if not tackled; and in consideration of the findings of this study that forensic accounting has a significant effect on fraud detection, the research made the below recommendations:

1. More forensic accountants should be employed by deposit money banks in Nigeria, considering the growing relevance of forensic accounting techniques in curbing modern day fraud and financial crime brought about by advancement in technology, changes in the modus operandi of banks in developing economies like that of Nigeria and in line with the findings of this study that revealed that forensic accounting components are effective in fraud detection.

2. The APEX bank (Central Bank of Nigeria) in collaboration with all financial institutions in the country should establish an electronic fraud risk information center (similar to those in developed countries) and staffed by forensic accountants to help in tracking cases of banking frauds, considering that banking operations are accelerating digitally, the sector is vital to the nation's economy and the findings of this study that 
revealed that analyzing financial transactions is capable of detecting suspicious and fraudulent activities.

3. The researcher recommends that DMBs in Nigeria should incorporate automated control measures such as introduction of biometric authentication of transactions as it will serve as a major deterrent for fraud occurrence and a proactive measure in fraud detection.

4. The researcher recommends that Management of DBMs should ensure continuous training and retraining of Forensic accounting units/Fraud management desk personnel to be abreast with latest trends as mode of banking transactions are changing continuously with advancement in technology; as no technique will succeed without efficient personnel.

5. The researcher also recommends that Deposit Money Banks in Nigeria should enhance the communication mediums on the various applications made available for their customers usage to serve as proactive measure in fraud detection. Applications such as Online banking platforms, Mobile banking applications, Unstructured Supplementary Service Data (USSD) codes should also avail customers' tools to block their accounts when they suspect a fraudulent activity, rather than waiting to visit a banking hall or call customer care centers. Such service will enhance curbing fraud online real-time.

\section{Limitation of the Study}

1. The research was based on financial fraud in the Deposit Money Banks, which in the opinion of many could be viewed as a sensitive matter and the targeted respondents were from specialized units such as Internal Control, hence, many were reluctant to fill the questionnaire. However, the researcher was able to convince the respondent that information provided was strictly for academic purposes and will be treated with utmost confidentially.

2. The instrument for collection of data was questionnaire, which may limit the realization of in-depth analysis when compared to the use of other means like interview. However, the researcher ensured the questions were well-structured to obtain meaningful responses.

3. The accuracy of the study was limited to the honesty of the respondents, especially on matters pertaining to forensic accounting services and frauds in the banking sector as par the information given by the respondents. It is on this premise that the researcher targeted specialized units such as Internal Control and audit to respond to the questionnaires.

\section{Suggestions for Further Research}

The study generally looked at the impact of forensic accounting on fraud detection in Deposit Money Banks in Nigeria. A research of this nature cannot effectively cover all the issues that needed to be discussed on the subject matter of forensic accounting, fraud detection and the activities of Deposit Money Banks in Nigeria, considering facts such as materials, finance, time, sample size, etc. The following are the researcher's suggestion for further studies: 
1. The research considered Deposit Money Banks in Nigeria, future research on similar topic could consider other geographical area by adopting a 'cross-country' or 'crosscultural approach', which will broaden generalizability.

2. The banking sector was considered for the purpose of the research, for those who might decide to further study this topic should consider other sectors such as public, manufacturing, oil and gas, consumables, etc.

3. The basis for analyzing the research hypotheses was regression analysis. Other researches desiring to explore similar topic can use other analytical techniques/tools.

\section{REFERENCES}

Abiola, I. (2009). An assessment of fraud and its management in Nigeria commercial banks. European journal of social sciences, 10, 628-640

Adebisi. A.F (2009). The bankers' fortress, Lagos: Mega synergy Nigeria limited

Adegbie, F. F. \& Fakile, A. S. (2012). Economic and financial crime in Nigeria. Forensic accounting as antidote. British Journal of Arts and Social Sciences, 6(1), 37-50.

Aduwo, O.O. (2016). The role of forensic accounting in combating the menace of corporate failure. International journal of economics, commerce and management, 10(1), 640649.

Ahuja, A.V (2010). Cyber Crime in Banking Sector. Retrieved online June 20, 2016. http://www.scribd.com

Akenbor, C.O. \& Oghoghomeh, T. (2013). Forensic auditing and financial crime in Nigerian banks: a proactive approach. Business and management review, 4(2), 48-61

Akindele, R. I. (2011). Fraud as a negative catalyst in the Nigerian banking industry. Journal of emerging trends in economics and management sciences, 2(5), 357-363.

Akpa, A. (2011). Knowledge creation process: Concepts and application in social research. Makurdi: Aboki publishers.

Akwaja, C. (2015). Investigation: Nigerian banks lose N199bn to e-fraud. Retrieved January 21, 2016 from http://www.leadership.ng/news.

American Institute of Certified Public Accountants (AICPA), Committee on auditing procedure, internal control - elements of a coordinated system and Its importance to management and the independent public accountant, Statement on Auditing Standards No. 48 (AU320.27), AICPA, 1973

Arokiasamy, L. \& Cristal, L. S. (2009). Forensic accounting: Public acceptance towards occurrence of fraud detection. International journal of business and management. $145-160$

Augustine, E.A. \& Uagbale-Ekatah, R.E. (2014). The growing relevance of forensic accounting as a tool for combating fraud and corruption: Nigeria experience. Research journal of finance and accounting, 5(2), 71-77.

Auta. (2010). E-banking in developing economy: empirical evidence from Nigeria. Journal of applied quantitative methods, 5(2)

Berney, L. (2008). For online merchants, fraud prevention can be a balancing act. Cards \& payments, 21(2), 22-27. 
Bhasin, M.L. (2015). Menace of fraud in Indian banking industry: An empirical study. Australian journal of business and management research, 4(12), 1-13.

Bhasin, M. (2007). "Mitigating Cyber Threats to Banking Industry. The Chartered Accountant. April, 1618-1623

Bhattacharyya. M. (2010). Objectives of internal control. Retrieved online June 20, 2016

Bhattacharyya, D., Ranjan, R., Alisherov, F., \& Choi, M. (2009). Biometric Authentication-A review. International Journal of u- and e-Service, Science and Technology, 2(3)

Boynton, W.C. \& Johnson, R.N (2006). Modern auditing: assurance services, and the integrity of financial report. USA: hermitage publishers.

Bressler, L. (2011), The role of forensic accountants in fraud investigations: Importance of attorney and judge`s perceptions, Journal of finance and accountancy, 11(27), 1-9.

Cabole (2009), Forensic Accounting: A paper presented at the (Hilton Hotel Lagos), Certified public accountant Journal New York. Retrieved online June 20, 2016.

Central bank of Nigeria annual reports 2011-2014.

Chi-chi, O.A. \& Ebimobowei, A. (2012). Fraudulent activities and forensic accounting services of $\quad$ banks in Nigeria. Asian journal of business management, 4(2), 124129.

Chiezey, U. \& Onu, A.J.C. (2013). Impact of fraud and fraudulent practices on the performance of banks in Nigeria. British journal publishing, 15, 12-28.

Cole, C. (2009). Forensic Audit, Paper presented at Hilton Hotel Lagos on June 2, 2009. Retrieved online June 20, 2016.

Crumbley, D.L. (2001). Forensic Accounting: Older Than You Think. Journal of Forensic accounting. (2), $181-202$.

Dada, S.O., Owolabi, S.A. \& Okwu, A.T. (2013). Forensic accounting a panacea to alleviation of fraudulent practices in Nigeria. International journal of business, management and economics research, 4(5), 787-792.

Damagum, Y.M. (2005). Auditing theory and practice ( $2^{\text {nd }}$ ed). Zaria: ABU press.

Dhar, P. \& Sarkar, A. (2010). Forensic accounting: An accountant's vision. Vidyasagar University J. Commerce, 15(3): 93-104.

Efiong, E. J. (2012). Forensic accounting education: An exploration of level of awareness in developing economies - Nigeria as a case study. International journal of business and management, 7 (4). 26-34

Efiong, E. J. (2013). An exploration of forensic accounting education and practice for fraud prevention and detection in Nigeria. Leicester, De-Montfort University.

Eiya, O. \& Otalor, J.I. (2013). Forensic accounting as a tool for fighting financial crime in Nigeria. Research journal of finance and accounting, 4(6), 18-25.

Eliezer, O. \& Emmanuel, B. (2015). Relevance of forensic accounting in the detection and prevention of fraud in Nigeria. Historical research letter, 23, 17-25

Emeh, Y. \& Obi, J. O. (2013). An empirical analysis of forensic accounting and financial fraud in Nigeria. African Journal of Social Sciences, 4, 112-121.

Enofe, A.O., Idemudia, N.G. \& Emmanuel, G. U. (2015). Forensic accounting a panacea to fraud reduction in Nigeria firms. Journal of accounting and finance management, $1(6), 1-31$.

Enofe, A.O, Agbonkpolor, O.R. \& Edebiri, O.J. (2015). Forensic accounting and financial fraud. International journal of multidisciplinary research and development, 2(10), 305-312. 
Enofe, A.O., Utomwen, O.A. \& Danjuma, E. J. (2015). The role of forensic accounting in mitigating financial crimes. International journal of advanced academic research, $1-25$.

Enofe, A.O., Okpako, P.O. \& Atube, E.N. (2013). The impact of forensic accounting on fraud detection. European journal of business and management, 5(26), 61-73.

Freedman, D.A., (2005). Statistical models; theory and practice. New York: Cambridge University press

Gates, T. \& Jacob, K. (2009). Payments fraud: perception versus reality - a conference Summary. Economic prospective, 33(1), 7-15.

Grippo, F.J. \& Ibex, J.W. (2003). Introduction to forensic accounting. The National Public Accountant, Washington, 4.

Hoffmann, A.O. \& Birnbrich, C. (2012). The impact of fraud prevention on bank-customer relationship. International journal of business marketing. 30, 390-407.

Hopwood, W.S., Leiner, J.J., \& Young, G.R. (2012).Forensic accounting and fraud examination. 20th ed. New York: McGraw - Hill.

Hopwood, W. S., Leiner, J. J. \& Young, G. R. (2008). Forensic accounting. New York: McGraw-Hill/Irwin.

Howard S. \& Sheetz, M. (2006): Forensic accounting and fraud investigation for nonexperts, New Jersey, John Wiley and Sons Inc.

Idolor, E.J (2010). Bank fraud in Nigeria, underlying causes, effect and possible remedies. African journal of accounting, economics, finance and banking research, 6(6), 62-80.

Ingram, D. (2009). Objective of internal control. Retrieved online June 20, 2016.

Jagdish S. G. (2013). Lecture Notes on Forensic Accounting Investigations, department of accounting \& law, State University of New York at Albany. Retrieved June 20, 2016.

Jain .A (2005). Cyber Crime: Issues \& Threats and management. Delhi: Chawla offset Press

Kanniainen, L. (2010), "Alternatives for banks to offer secure mobile payments", International Journal of Bank Marketing, 28(5), 433-434.

Kanu, S.I. \& Okorafor, E.O. (2013). The nature, extent and economic impact of fraud on bank deposits in Nigeria. Interdisciplinary journal of contemporary research in business, 4(9), 253-265.

Kasum, A. S. (2009). The relevance of forensic accounting to financial crimes in private and public sectors of third world economies: A study from Nigeria. Proceedings of the 1st international Conference on Governance Fraud Ethics and Social Responsibility, June.

Keltie, A. (2009). Preventing and investigating fraud in the work place. Business crime. Retrieved online June 20, 2016.

Khan, M. S., \& Mahapatra, S. S. (2009). Service quality evaluation in internet banking: an empirical study in India. Int. J. Indian Culture and Business Management, 2(1), 30-46

Khanna, A. \& Arora, B. (2009). A study to investigate the reason for bank fraud and the implementation of preventive security controls in Indian banking industry. International journal of business science and applied management, 4, 1-21.

Koh, A.N., Arokasamy, L. \& Suat, C.L. (2009). Forensic accounting: public acceptance towards occurrence of fraud detection. International journal of business and management, 4(11), 145-149.

Kosmas, N., Thulani, D., \& Edwin, M. (2009). The effectiveness of forensic auditing in detecting, investigating, and preventing bank frauds. Journal of sustainable development in Africa, 10(4), 405-425 
Malphrus, S. (2009). Perspectives on retail payments fraud. Economic Perspectives, 33(1), 31-36.

Masocha, R., Chiliya, N. \& Zindiye S, (2010). E-banking adoption by customers in the rural milieus of South Africa: A case of Alice, Eastern Cape, South Africa. Retrieved online June 20, 2016

McDonnell, N.K. (2015). Payments fraud and control survey. Association of financial professionals' journal. Underwritten by J P Morgan. Retrieved online June 20, 2016.

McMahon, R., Serrato, D., Bressler, L. \& Bressler, M. (2015). Fighting cybercrime calls for developing effective strategy. Journal of technology research, 6, 1-15.

Mercer, G. (2006). Audit internal control. Atlanta: Mercer university press.

Modugu, K.P. \& Anyuduba, J.O. (2013). Forensic accounting and financial fraud in Nigeria: An empirical approach. International journal of business and social sciences, 4(7), 281-289.

Moore. T, Clayton. R \& Anderson. R (2009). The Economics of Online Crime. Journal of economic perspectives, $23 \square 3 \square, 3-20$

Mukoro, O.D., Faboyede, O.S. \& Eziamaka, C.B. (2014). The effectiveness of forensic accountants in strengthening internal control of business organizations in Nigeria. Journal of management research, 6(1), 40-69.

Mutesi, J. (2011). Information sharing, risk management and financial performance of commercial banks in Uganda. Journal of emerging issues in economics, finance and banking, 2(2).

Ngalyuka, C. (2013). The relationship between ICT utilization and fraud losses in commercial banks in Kenya. International journal of business and public management, 2(3), 56-59.

NIBSS Annual Report 2014, 2015.

Njenga, N., \& Osiemo, P. (2013). Effect of fraud risk management on organization performance: A case of deposit taking microfinance institutions in Kenya. International journal of social sciences and entrepreneurship, 1(7), 1-17.

Nwankwo, O. (2013). Implication of fraud on commercial banks performance in Nigeria. International journal of business and management, 8(15), 144-150.

Nwosu, P. (2015). CBN's move to check e-fraud. http://www.sunnewsonline.com/new/cbn. Retrieved online June 20, 2016.

Obaseki, O.O. (2006). Elements of domestic operation in Nigerian banks. Lagos: Begmeth 10 ventures.

Oboh, G. A. (2005). Selected essays on contemporary issues in the Nigerian banking system. Ibadan: University press ltd.

Odelabu, A.T. (2014). Effect of forensic accounting on financial performance of commercial banks in Nigeria. Research journal of finance and accounting, 5(8), 103-109

Okoye E.I \& Akamobi N.L (2009): The role of forensic accounting in fraud investigation and litigation support. The Nigerian academic forum, 17(1).

Okoye, E. I. \& Gbegi, D. O. (2013). Forensic accounting: A tool for fraud detection and prevention in the public sector. (A study of selected ministries in Kogi state). International Journal of Academic Research in Business and Social Sciences, $3(3), 1-19$.

Okunbor. J.A \& Obaretin. O (2010): Effectiveness of the application of forensic accounting services in Nigerian corporate organizations. AAU JMS. 1(1).

Oladejo, M.O. \& Oluwaseun, Y. (2015). Impact of forensic accounting on fraud reduction in Nigerian banking sector. International journal of empirical finance, 4(4), 250-257. 
Olaoye, C.O. \& Dada, R.A. (2014). Analysis of fraud in banks: Nigeria's experience. European journal of business and management, 6(31), 90-99.

Oloidi, G.A. \& Ajinaja, O.T. (2014). Bank fraud and forgeries in Nigeria: A study of the causes, types, detection and prevention. Journal of economics and commerce, 4(2), 41-50.

Olufunke, O.O, (2010). Computer Crimes and Counter Measures in the Nigerian Banking Sector. Journal of Internet Banking and Commerce $\square \square \square \square 1 \square, 2$

Omondi, E.O, (2013). The impact of forensic accounting services on fraud detection and prevention among commercial banks in Kenya. Unpublished masters' dissertation, University of Nairobi, Kenya.

Onodi, B.E., Okafor, T.G. \& Onyali, C.I. (2015). The impact of forensic investigative method on corporate fraud deterrence in banks in Nigeria. European journal of accounting, auditing and finance research, 3 (4), 69-85.

Onwujiuba, M. (2014). Overview and Impact of fraud in the commercial banks in Nigeria (A case study of first bank of Nigeria PLC). International journal of research in management, economics and commerce, 2(3).

Owojori, A.A \& Asaolu T. O. (2009): The role of forensic accounting in solving the vexed problem of corporate world. European Journal of Scientific Research. 29(2).183-187

Peter, Z., Masoyi, A.D., Ernest, E.I. \& Gabriel, A.O. (2014). Application of forensic auditing in reducing fraud cases in Nigeria money deposit banks. Global journal of management and business research, 14(3), 14-22.

Reddy, G.N. (2009). IT- Based Banking Services Enhancing Efficiency. Financial Analyst. $\square$ November, 69.

Saddique, I \& Richman, S. (2011). Impact of electronic crime in Indian banking sector. International journal of information technology, 1, 159-164.

Sang, M.J (2012). Determinants of fraud control measures in commercial banks: A Survey of selected commercial banks in Nakuru Town, Kenya. International journal of science and research (IJSR) 3(10), 2178-2183

Sanusi, S. L. (2010). The Nigerian banking industry-what went wrong and the way forward. A lecture delivered at the Bayero University, Kano, on Friday February 26, 2010.

Shah, M.H., (2012). Critical Success Factors in e-Banking: A Study of Two UK Retail Banks

Sidden, K. \& Simmons, D. (2005). Banking on security. American City \& County, 120(11), 30 http://search.ebscohost.com

Singleton, T. W \& Singleton, A. J. (2006). Fraud Auditing and Forensic Accounting. 3rd ed.

Smith, G. \& Crumbley, D. (2009). How divergent are pedagogical views toward the fraud/forensic accounting curriculum? Global Perspectives on Accounting Education. $6,1-24$.

Stanbury, J \& Paley-Menzies, C. (2010). Forensic futurama: Why forensic accounting is evolving. Available at http://www.aicpa.org/Publications/Newsletters June 28, 2010.

Sullivan, R.J. (2010). The changing nature of U.S. card payment fraud: industry and public policy options. Economic Review, 95(2), 101-33.

Tariq T.Y.A, Moayad, M.A.A, Sofri, Y and Ala, M.A.R (2013). The Role of Forensic Accounting in Reducing Financial Corruption: A Study in Iraq. International Journal of Business and Management; 9 (1), 26-34

Tilton, P. (2006). Guide to prevent work place fraud. Retrieved online June 20, 2016. http://www.chubb.com 
Usman, A.K. \& Shah, M.H. (2013). Critical success factors for preventing e-banking fraud. Journal of internet banking and commerce. August, 18(2), 1-14.

Wang, W. \& Yen, Y.M. (2005). General guidelines of internal control over internet-based electronic commerce. Taiwan: APDSI, Taipei.

Wanyama, T. S. (2012). Effectiveness of fraud response strategies adopted by cooperative bank of Kenya Limited. International Journal of Economics and Finance, 2(2).

Watterston, J. (2014). Fraud and corruption control framework, 2014-2016. Australian national audit office

Whittington, O.R. \& Pany, K. (2001). Principles of auditing and other assurance services $\left(13^{\text {th }} \quad\right.$ ed.). New York: Mc Graw Hill.

Wilhelm, W.K. (2004). The fraud management lifecycle theory: a holistic approach to fraud management. Journal of economic crime management, 2 (2), 1-38

Zadeh, H.E. \& Ramazani, M. (2012). Accountant's perception of forensic accounting (case study of Iran). Global journal of management and business research, 12(6), 1-4.

Zimbleman, M.K. (1997). The effects of SAS No. 82 on auditors' attention to fraud risk factors and audit planning. Journal of accounting Research, (Supplement), pp. 75 97.

Zimbleman, M.K., Albrecht, C.C., Albrecht, S.W. \& Albrecht, C.O. (2012).Forensic accounting, Cengage Learning, International edition Canada, 4, 429. 


\section{APPENDIX I}

LIST OF DEPOSIT MONEY BANKS OPERATING IN NIGERIA AS AT MAY 25, 2016.

DEPOSIT MONEY BANKS LICENCE WITH INTERNATIONAL AUTHORIZATION
\begin{tabular}{|l|l|}
\hline NAME OF INSTITUTION & HEAD OFFICE ADDRESS \\
\hline ACCESS BANK PLC & $999 \mathrm{c}$, Danmole Street, Victoria Island, Lagos \\
\hline DIAMOND BANK PLC & Plot 1261, Adeola H Street, Victoria Island, Lagos \\
\hline FIDELITY BANK PLC & 2, Kofo Abayomi Street, Victoria Island, Lagos \\
\hline FIRST CITY MONUMENT BANK PLC & Primose Towers, 17a, Tinubu Street, Lagos \\
\hline FIRST BANK NIGERIA LIMITED & Samuel Asabia House, 35 Marina, Lagos \\
\hline GUARANTY TRUST BANK PLC & 635, Akin Adesola Street, Victoria Island, Lagos \\
\hline SKYE BANK PLC & 3, Akin Adesola Street, Victoria Island, Lagos \\
\hline UNION BANK OF NIGERIA PLC & Stallion Plaza, 36 Marina, Lagos \\
\hline UNITED BANK OF AFRICA PLC & 57 Marina, Lagos \\
\hline ZENITH BANK PLC & Plot 84,Adeogun Street, Victoria Island, Lagos \\
\hline
\end{tabular}

\section{DEPOSIT MONEY BANKS LICENCE WITH NATIONAL AUTHORIZATION}

\begin{tabular}{|l|l|}
\hline CITIBANK NIGERIA LIMITED & 27, Kofo Abayomi Street, Victoria Island, Lagos \\
\hline ECOBANK NIGERIA PLC & 21, Ahmadu Bello Way, Victoria Island, Lagos \\
\hline HERITAGE BANK LIMITED & $\begin{array}{l}\text { 292, Ajose Adeogun Street, Victoria Island, } \\
\text { Lagos }\end{array}$ \\
\hline KEYSTONE BANK LIMITED & $\begin{array}{l}\text { Walter Carrington Crescent, Victoria Island, } \\
\text { Lagos }\end{array}$ \\
\hline STANBIC IBTC BANK PLC & $\begin{array}{l}142, \text { Ahmadu Bello Way, Victoria Island, Lagos } \\
\text { STANDARD CHARTERED BANK } \\
\text { LIMITED }\end{array}$ \\
\hline STERLING BANK PLC & Sterling Towers, 20 Marina, Lagos \\
\hline UNITY BANK PLC & Plot 497, Abogo Largema Street, CBD, Abuja \\
\hline WEMA BANK PLC & Wema Towers, 54 Marina, Lagos Island, Lagos \\
\hline
\end{tabular}

DEPOSIT MONEY BANKS LICENCE WITH REGIONAL AUTHORIZATION

\begin{tabular}{|l|l|}
\hline SUNTRUST BANK NIGERIA LIMITED & $\begin{array}{l}1, \text { Oladele Olashore Street, Victoria Island, } \\
\text { Lagos }\end{array}$ \\
\hline PROVIDUSBANK PLC & 54, Adetokunbo Street, Victoria Island, Lagos \\
\hline
\end{tabular}

NON-INTEREST BANK LICENCE WITH NATIONAL AUTHORIZATION

\begin{tabular}{|l|l}
\hline JAIZ BANK LIMITED & Plot 73, Ralph Shodeinde Street, CBD, Abuja
\end{tabular}




\section{APPENDIX II}

\section{REGRESSION}

\section{REGRESSION}

/MISSING LISTWISE

/STATISTICS COEFF OUTS R ANOVA

$/$ CRITERIA $=$ PIN $(.05) \quad \operatorname{POUT}(.10)$

/NOORIGIN

/DEPENDENT SectionA2

/METHOD=ENTER SectionB2 Sectionc4 Sectiond3.

\begin{tabular}{|l|r|r|r|r|}
\hline \multicolumn{5}{|c|}{ Model Summary } \\
\hline $\begin{array}{l}\text { Mode } \\
\mathrm{I}\end{array}$ & $\mathrm{R}$ & $\begin{array}{c}\mathrm{R} \\
\text { Square }\end{array}$ & $\begin{array}{c}\text { Adjusted R } \\
\text { Square }\end{array}$ & $\begin{array}{c}\text { Std. Error of } \\
\text { the } \\
\text { Estimate }\end{array}$ \\
\hline 1 & $.440^{\mathrm{a}}$ & .193 & .164 & .587 \\
\hline
\end{tabular}

a. Predictors: (Constant), conducting investigation, analyzing financial transactions, reconstruction of incomplete accounting records

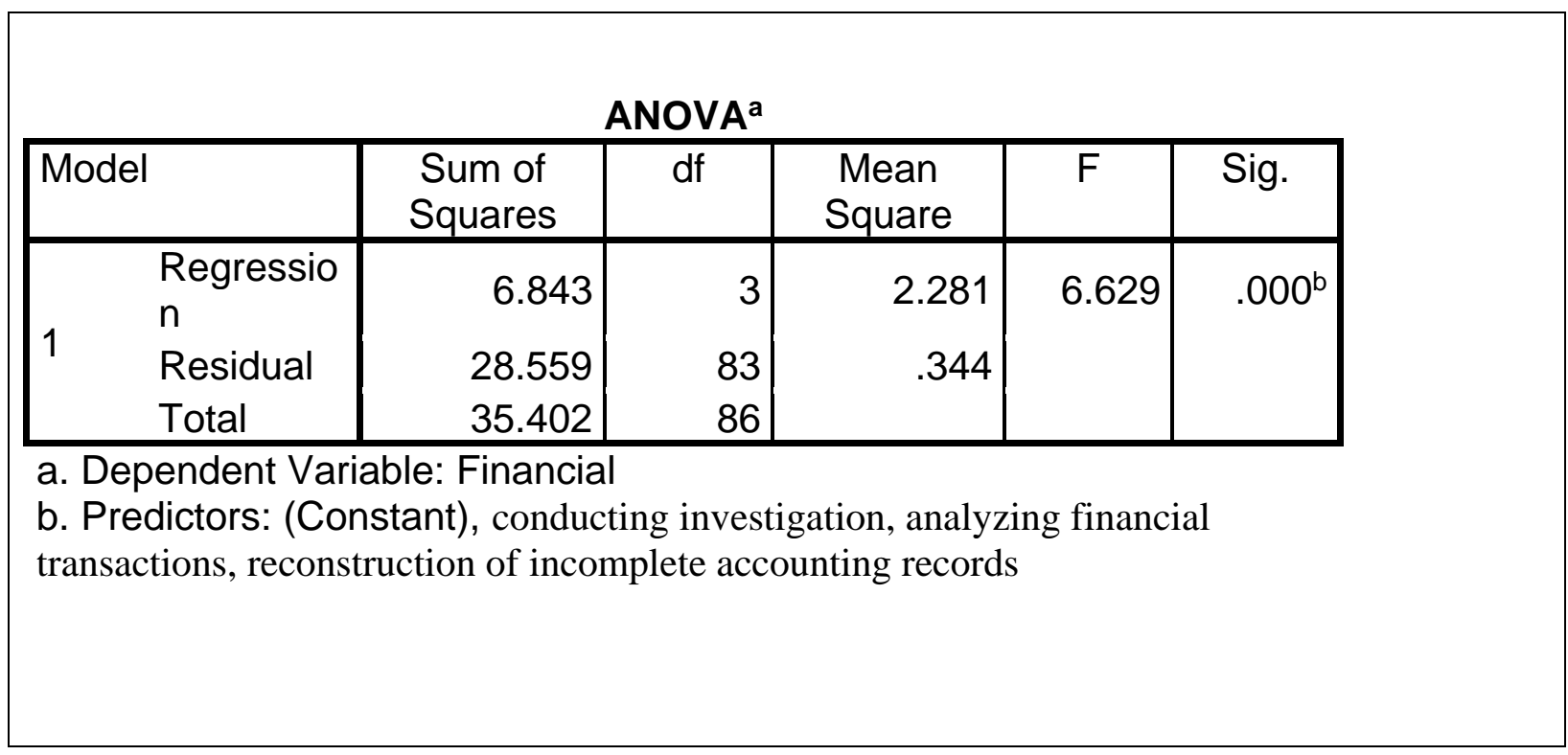

